The University of Maine

\title{
DigitalCommons@UMaine
}

Marine Sciences Faculty Scholarship

School of Marine Sciences

3-15-2002

\section{Hydrographic Conditions Off Northern Chile During the 1996-1998 La Niña and El Niño Events}

\author{
J.L. Blanco \\ M.E. Carr \\ Andrew Thomas \\ University of Maine - Main, thomas@maine.edu \\ P. T. Strub
}

Follow this and additional works at: https://digitalcommons.library.umaine.edu/sms_facpub

\section{Repository Citation}

Blanco, J. L.; Carr, M. E.; Thomas, Andrew; and Strub, P. T., "Hydrographic Conditions Off Northern Chile During the 1996-1998 La Niña and El Niño Events" (2002). Marine Sciences Faculty Scholarship. 57.

https://digitalcommons.library.umaine.edu/sms_facpub/57 


\title{
Hydrographic conditions off northern Chile during the 1996- 1998 La Niña and El Niño events
}

\author{
Jose Luis Blanco, ${ }^{1,2}$ Mary-Elena Carr, ${ }^{3}$ Andrew C. Thomas, ${ }^{4}$ and P. Ted Strub ${ }^{5}$ \\ Received 17 February 2000; revised 4 May 2001; accepted 8 May 2001; published 8 March 2002.
}

[1] The evolution of oceanographic conditions in the upwelling region off northern Chile $\left(18^{\circ}-24^{\circ} \mathrm{S}\right)$ between 1996 and 1998 (including the 1997-1998 El Niño) is presented using hydrographic measurements acquired on quarterly cruises of the Chilean Fisheries Institute, with sea surface temperature (SST), sea level, and wind speeds from Arica $\left(18.5^{\circ} \mathrm{S}\right)$, Iquique $\left(20.5^{\circ} \mathrm{S}\right)$, and Antofagasta $\left(23.5^{\circ} \mathrm{S}\right)$ and a time series of vertical temperature profiles off Iquique. Spatial patterns of sea surface temperature and salinity from May 1996 to March 1997 followed a normal seasonal progression, though conditions were anomalously cool and fresh. Starting in March 1997, positive anomalies in sea level and sea surface temperature propagated along the South American coast to $37^{\circ} \mathrm{S}$. Maximum sea level anomalies occurred in two peaks in MayJuly 1997 and October 1997 to February 1998, separated by a relaxation period. Maximum anomalies $\left(2^{\circ} \mathrm{C}\right.$ and 0.1 practical salinity units (psu)) extended to $400 \mathrm{~m}$ in December 1997 within $50 \mathrm{~km}$ of the coast. March 1998 presented the largest surface anomalies $\left(>4^{\circ} \mathrm{C}\right.$ and $\left.0.6 \mathrm{psu}\right)$. Strong poleward flow (20-35 $\mathrm{cm} \mathrm{s}^{-1}$ ) occurred to $400 \mathrm{~m}$ or deeper during both sea level maxima and weaker $\left(10 \mathrm{~cm} \mathrm{~s}^{-1}\right)$ equatorward flow followed each peak. By May 1998, SST had returned to the climatological mean, and flow was equatorward next to the coast. However, offshore salinity remained anomalously high owing to a tongue of subtropical water extending southeast along the Peruvian coast. Conditions off northern Chile returned to normal between August and December 1998. The timing of the anomalies suggests a connection to equatorial waves. The progression of the 1997-1998 El Niño was very similar to that of 1982-1983, though with different timing with respect to seasons. INDEX TERMS: 4516 Oceanography: Physical: Eastern boundary currents; 4522 Oceanography: Physical: El Niño; 4219 Oceanography: General: Continental shelf processes; KEYWORDS: El Niño, Humboldt Current, Hydrography, Northern Chile

\section{Introduction and Background}

\subsection{Introduction}

[2] The coastal ocean off northern Chile between $18^{\circ}$ and $24^{\circ} \mathrm{S}$ (Figure 1) is characterized by wind-driven coastal upwelling, which leads to elevated biological productivity. The region is embedded in the Peru-Chile Current System. Water flowing eastward in the South Pacific Current (West Wind Drift) reaches Chile between $35^{\circ}$ and $45^{\circ} \mathrm{S}$ and splits into the southward flowing Cape Horn Current and the northward flowing Peru-Chile Current, also known as the Humboldt or Peru Current. Although the circulation in this region is often portrayed in schematics as simply equatorward, it is a complex system [Strub et al., 1998] comprising nearshore and offshore equatorward branches, a poleward undercurrent next to the coast, and one or more surface poleward countercurrents that may be connected to the undercurrent.

[3] Monthly averaged winds off northern Chile blow from the south or southwest year-round with speeds of $3-6 \mathrm{~m} \mathrm{~s}^{-1}$. The

\footnotetext{
${ }^{1}$ Instituto de Fomento Pesquero, Valparaíso, Chile.

${ }^{2}$ Now at Center for Coastal Physical Oceanography, Old Dominion University, Norfolk, Virginia, USA.

${ }^{3}$ Jet Propulsion Laboratory, California Institute of Technology, Pasadena, California, USA.

${ }^{4}$ School of Marine Sciences, University of Maine, Orono, Maine, USA.

${ }^{5}$ College of Oceanic and Atmospheric Sciences, Oregon State University, Corvallis, Oregon, USA.
}

Copyright 2002 by the American Geophysical Union. 0148-0227/02/2001JC001002 maximum is in austral summer, unlike off the Peruvian coast where the maximum wind occurs in fall-winter. Wind speeds are lower, and the seasonal cycle is weaker in the northeast corner, where the coastline changes from a zonal to a more meridional orientation. The equatorward winds drive coastal upwelling, which lifts the thermocline/nutricline, supplying nutrients to the surface and enabling phytoplankton growth. This translates into a strong fishery for small pelagic fish. Approximately two million metric tons of anchovy and sardines are landed during normal years off northern Chile and make up one third of the total Chilean catch.

[4] The seasonal variation in the hydrographic patterns in this region results from the solar cycle and shifts in transport of the major upper ocean water masses. Long-term hydrographic measurements of the region [Blanco et al., 2001] have been used to define the regional characteristics of these water masses. The warm $\left(>18.5^{\circ} \mathrm{C}\right)$ and salty $(>34.9)$ Subtropical Water (STW), observed at the surface, has its source northwest of Peru. The cooler $\left(\sim 12.5^{\circ} \mathrm{C}\right)$ and relatively salty $(34.7-34.9)$ Equatorial Subsurface Water (ESSW) makes up the poleward undercurrent between 100 and $300 \mathrm{~m}$ depth near the continental slope. STW and ESSW are of equatorial/subtropical origin, and their influence is maximum in the northern portion of the study area and decreases to the south. The cool $\left(\sim 12^{\circ}\right)$ and fresh $(\sim 34.25)$ Subantarctic Water (SAW) has a far southern source and is found below the STW offshore and above the ESSW closer to the coast. Below $500 \mathrm{~m}$ the influence of the cold $\left(\sim 7^{\circ}\right)$ and fresh $(\sim 34.4)$ Antarctic Intermediate Water (AAIW) can be seen. SST and surface salinity present a strong cross-shelf gradient in spring and summer due to warming of offshore waters and upwelling of cool, fresher water (a combination of ESSW from the poleward undercurrent and SAW) near the coast. The meridional gradient 

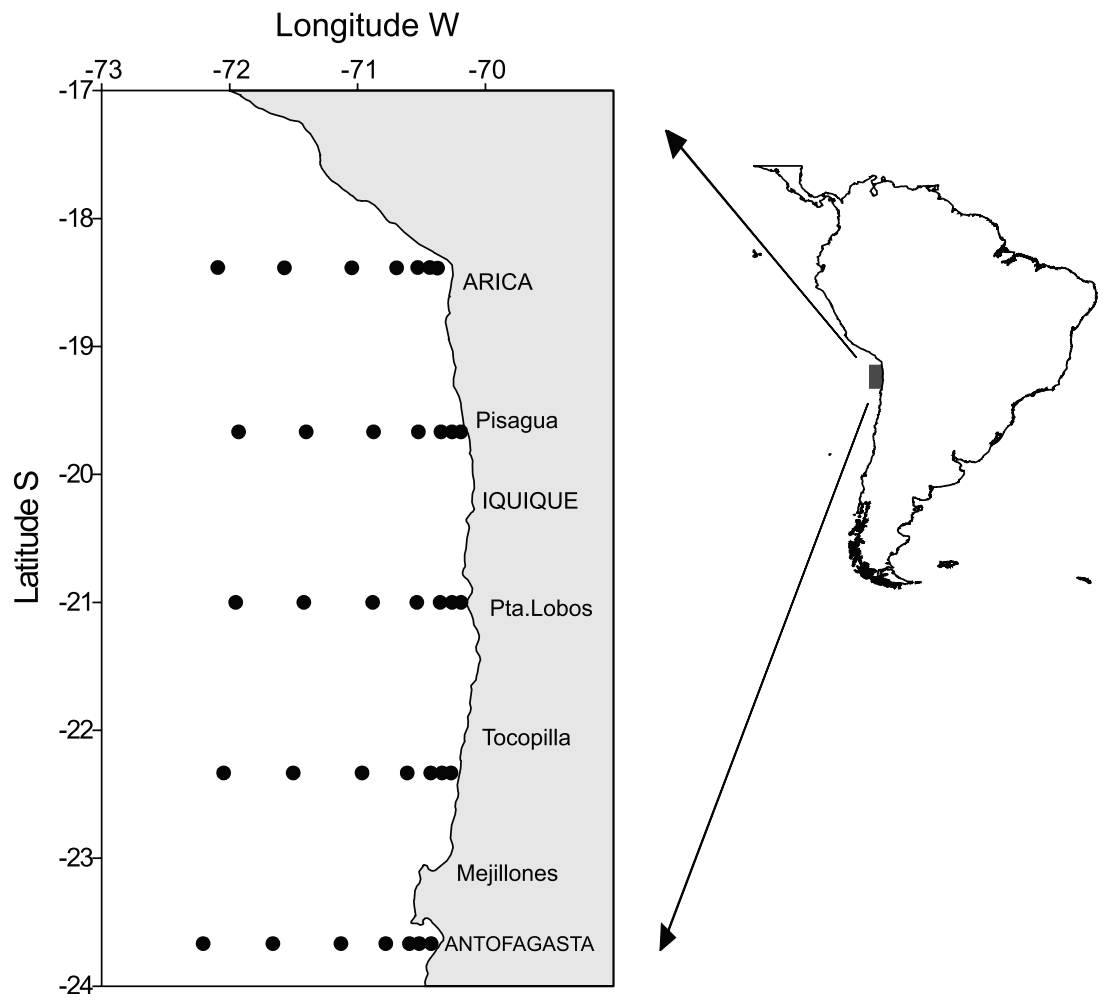

Figure 1. Map of study region, transects, and stations for hydrographic cruises. The coastal time series was carried out off Iquique at $20.5^{\circ} \mathrm{S}$.

results from the northern influence of warm, salty STW at the surface. In winter and fall the surface fields are usually homogeneous with a weak north-south gradient. Blanco et al. [2001] describe the climatological seasonal cycles of wind forcing, water properties, and circulation between $18^{\circ}$ and $24^{\circ} \mathrm{S}$.

[5] This region is subject to large interannual variability associated with the El Niño-Southern Oscillation (ENSO) "cycle". Conditions that are typically attributed to the El Niño or warm phase include [Bernal et al., 1982; Blanco and Díaz, 1985; Fonseca, 1985] enhanced poleward transport of warm, saline water of equatorial origin at the surface and in the poleward undercurrent, high sea levels and SST, and low oxygen concentrations. Equatorial waves also propagate into the region as coastal trapped waves with periods of 5-50 days [Enfield et al., 1987; Shaffer et al., 1997]. The poleward advection of equatorial water at the surface (due to waves or increased poleward currents) depresses the thermocline and nutricline, thus reducing primary productivity. Although the relationship between oceanographic conditions and fish production is complex, El Niño periods tend to coincide with both a reduction in fish biomass and with changes in the dominant species from anchovy to sardine.

\subsection{El Niño off Chile}

[6] Philander [1990], Neelin et al. [1994], Battisti and Sarachik [1995], and Neelin and Latif [1998] review the equatorial dynamics of atmosphere and ocean associated with the ENSO phenomenon. Strub et al. [1998] summarize past observations of El Niño effects along the coast of Ecuador, Peru, and Chile. The physical aspects of interest include (1) changes in sea level and currents, (2) changes in the distributions (horizontal and vertical) of water properties, (3) the connection between local conditions and local and distant forcing, and (4) links to the biology. Here we consider the first three, reserving a description of the biological conditions for a separate analysis.
[7] The connection between changing coastal conditions off Ecuador, Peru, and Chile and equatorial waves and currents was clearly established during the 1982-1983 El Niño. Increased SST and depth of isotherms along the equator at $82.5^{\circ} \mathrm{W}$ preceded changes in October 1982 at $2^{\circ} \mathrm{S}$ (La Libertad) by 2 months [Cucalon, 1987] and changes at $10^{\circ} \mathrm{S}$ off Peru followed within days [Smith, 1983; Huyer et al., 1987]. Off Chile the event was tracked in sea level down the coast to at least $33^{\circ} \mathrm{S}$ [Fonseca, 1985; Bilbao, 1992]. Tide gauge and current meter data have been used to connect coastal trapped waves (CTW) along Peru and Chile and the equatorial wave guide [Smith, 1978; Brink, 1982; Enfield et al., 1987; Cornejo and Enfield, 1987; Shaffer et al., 1997]. Shaffer et al. [1997] recently identified CTWs with nominal periods of 5, 10, and 50 days in current meter records along the Chilean continental slope at $30^{\circ} \mathrm{S}$ and found a connection with currents and winds $15,000 \mathrm{~km}$ away on the equator at the international date line. CTWs are thought to increase in strength during the onset of El Niño events [Enfield et al., 1987; Shaffer et al., 1997].

[8] Persistent and strong currents, associated or not with waves, are capable of advecting water masses long distances. The onset of El Niño off Peru is signaled by increased poleward currents for $\sim 2$ months. The average current speed over the shelf at $55 \mathrm{~m}$ depth during the El Niño period of April-May 1976 at $15^{\circ} \mathrm{S}$ was $23 \mathrm{~cm} \mathrm{~s}^{-1}$ compared to $9 \mathrm{~cm} \mathrm{~s}^{-1}$ during a similar period a year later [Smith, 1983]. Similarly, currents over the shelf at $100 \mathrm{~m}$ depth at $10^{\circ} \mathrm{S}$ increased to $25 \mathrm{~cm} \mathrm{~s}^{-1}$ during October-November 1982, compared to $4 \mathrm{~cm} \mathrm{~s}^{-1}$ the previous year [Smith, 1983]. The accelerated flow translates over a 2 month period to an increased displacement of $700-1000 \mathrm{~km}$ $\left(7^{\circ}-10^{\circ}\right.$ of latitude)

[9] Changes in the distribution of water properties result from the horizontal and vertical displacement of water masses. Blanco and Díaz [1985] documented the appearance off northern Chile of warmer and saltier surface water in December 1982 and its disappearance in December 1983. Fonseca [1985] traced increased 

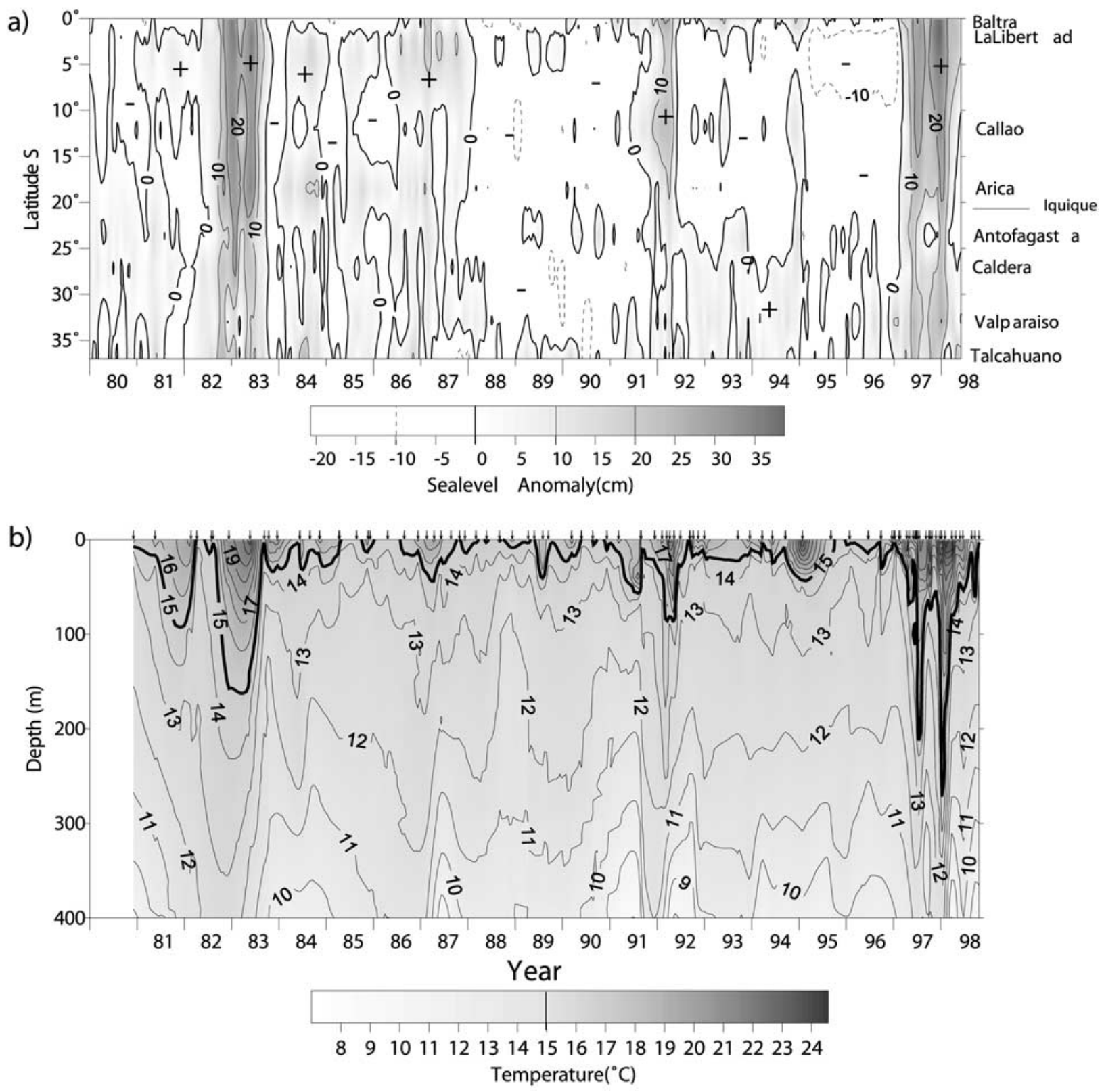

Figure 2. (a) Time-latitude plot of monthly sea surface height anomalies from coastal tide gauges along the west coast of South American (locations at the right) from 1980 to 1996. Plus and minus indicate the sign of the anomaly; (b) time-depth plot of temperatures $10 \mathrm{~km}$ offshore of Iquique. Sampling is indicated by arrows. See color version of this figure at the back of this issue.

SSTs at Chilean harbors to $35^{\circ} \mathrm{S}$ (Talcuahano) in early 1983. Lower oxygen concentrations along the coast were attributed to increased transport in the poleward undercurrent [Fonseca, 1985]. This is consistent with the increased volume (and temperature) of ESSW (with respect to climatological values) from December 1982 to June 1983 off Antofagasta and Arica [Blanco and Díaz, 1985]. Changes in vertical distributions are usually noted as displaced isotherms. Deepened surface isotherms were seen offshore at $10^{\circ} \mathrm{S}$ in November 1982 [Huyer et al., 1987] and at $18^{\circ}, 20.5^{\circ}$, and $24^{\circ} \mathrm{S}$ in December 1982 [Blanco and Díaz, 1985]. An exact date of isotherm deepening is unknown as there were no transects for many months prior to November.
[10] It was originally thought that changes in sea level and thermocline depth were caused by a decrease or reversal of local upwelling-favorable winds. However, measured winds off central Peru [Smith, 1983] during both the 1976 and 1982-1983 warm periods continued to be strongly equatorward. Equatorward winds at the coast actually increased at $12^{\circ} \mathrm{S}$ during the $1982-1983$ event but decreased at $5^{\circ} \mathrm{S}$, responding to changes in the location of the Intertropical Convergence Zone (ITCZ) and the South Pacific High [Huyer et al., 1987]. Fonseca [1985] indicates that even though the South Pacific High weakened during parts of the 1982-1983 El Niño, Chilean coastal winds were still equatorward and therefore upwelling-favorable. 


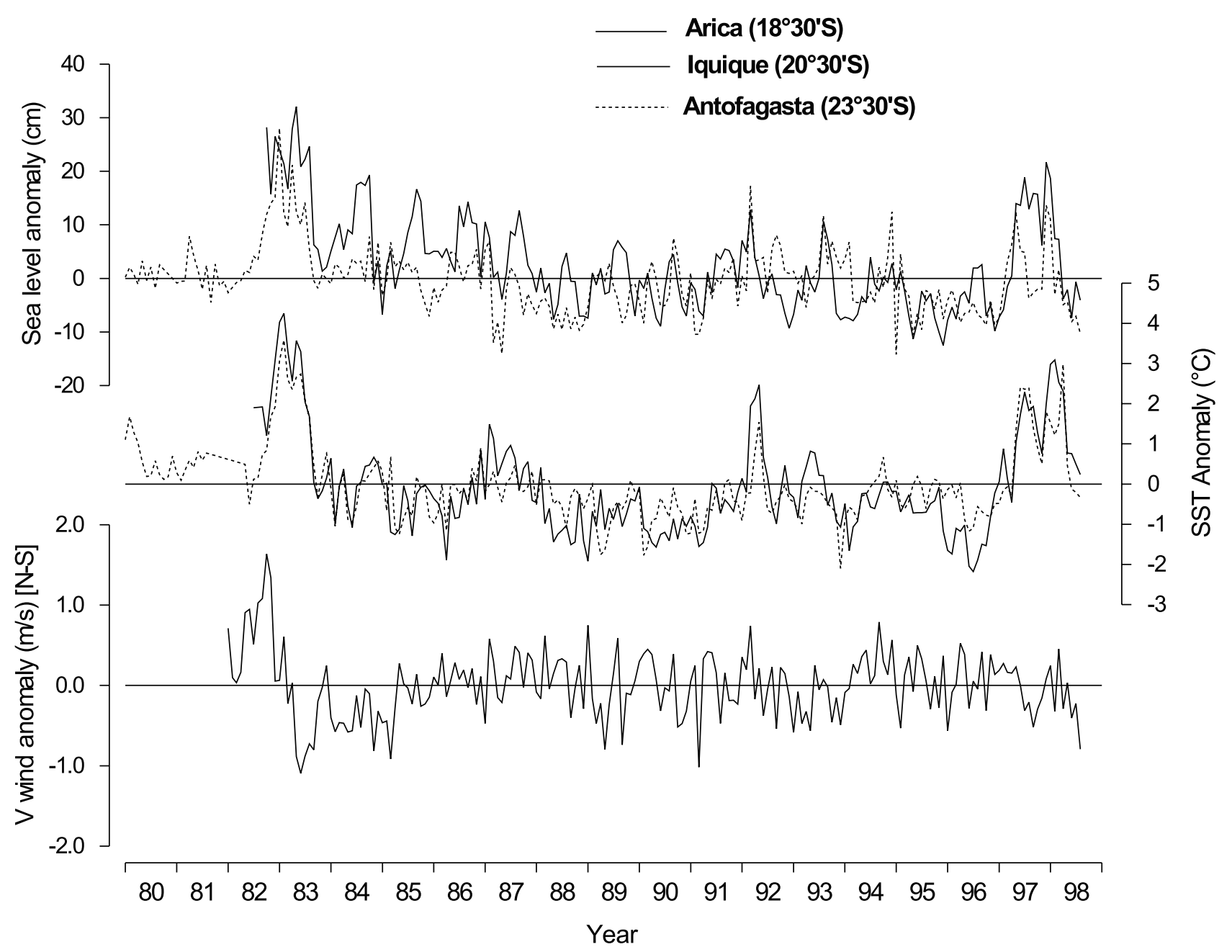

Figure 3. (a) Monthly anomalies of sea level and SST at Arica and Antofagasta and alongshore wind speed at Iquique for 1980-1998. (b) Monthly anomalies of the same variables for 1995-1998 from all three stations.

[11] Below we examine the changes in forcing and ocean conditions off northern Chile during the 1996-1998 period. Quarterly surveys carried out by the Chilean Fisheries Institute, Instituto de Fomento Pesquero (IFOP), allow a more detailed analysis than was previously possible. Likewise, a recently compiled hydrographic climatology, consisting of 30 years of physical conditions and circulation [Blanco et al., 2001], provides a basis against which to quantify the magnitude of the observed changes. Section 2 describes the sources of data used in the study. The results are presented in section 3 , followed by discussion in section 4 and a summary in section 5 .

\section{Data and Methods}

\subsection{Hydrographic Surveys}

[12] IFOP presently makes quarterly hydrographic surveys off northern Chile between $18^{\circ}$ and $24^{\circ} \mathrm{S}$ (Figure 1). This study focuses on data from nine of these cruises (May 1996 to May 1998) during which seven stations are occupied along each of five offshore transects separated by $148 \mathrm{~km}$ (35 stations total). Stations were located $1.8,9.2,18.5,37,74,129.6$, and $185 \mathrm{~km}$ from the coast. Temperature and salinity were measured continuously to 500 dbar with a SeaBird conductivity-temperature-depth (CTD) profiler (model 19) equipped with a General Oceanics rosette with 12 Niskin bottles of 1.7 L. Oxygen concentrations were calculated using the modified Winkler titration method. Salinities measured with Autolab induction salinometers from water samples collected at standard depths and temperatures from reversing thermometers were used to calibrate the CTD. Over 30 years $(1964-1996)$ of data collected in similar surveys were used to calculate a climatological mean to quantify anomalous conditions. Since the sampling period spanned the three El Niño events as well cold periods (e.g., 1988), the climatological mean is representative of both "normal" and anomalous conditions. Blanco et al. [2001] present the 3 month (seasonal) climatology of the region. Anomalies of the variables for the nine cruises discussed here were calculated using a monthly climatology of the 30 year data set [Blanco, 1996] to minimize possible noise due to the cruise occurring at the begining or end of a season.

\subsection{Time Series From Coastal Locations}

[13] Wind speeds from 1970 to 1998 were obtained from the Dirección Meteorológica de Chile for airports located near Arica $\left(18.5^{\circ} \mathrm{S}\right)$, Iquique $\left(20.5^{\circ} \mathrm{S}\right)$, and Antofagasta $\left(23.5^{\circ} \mathrm{S}\right)$. Monthly sea surface heights (1975-1998), adjusted for the inverse barometer effect, were obtained from the University of Hawaii Sea Level Center for tide gauges at Arica and Antofagasta. Monthly sea surface temperatures (SST) calculated at Arica, Iquique, and Antofagasta during 1960-1997 were provided by the Servicio Hidrográfico y Oceanográfico de la Armada de Chile. The clima- 


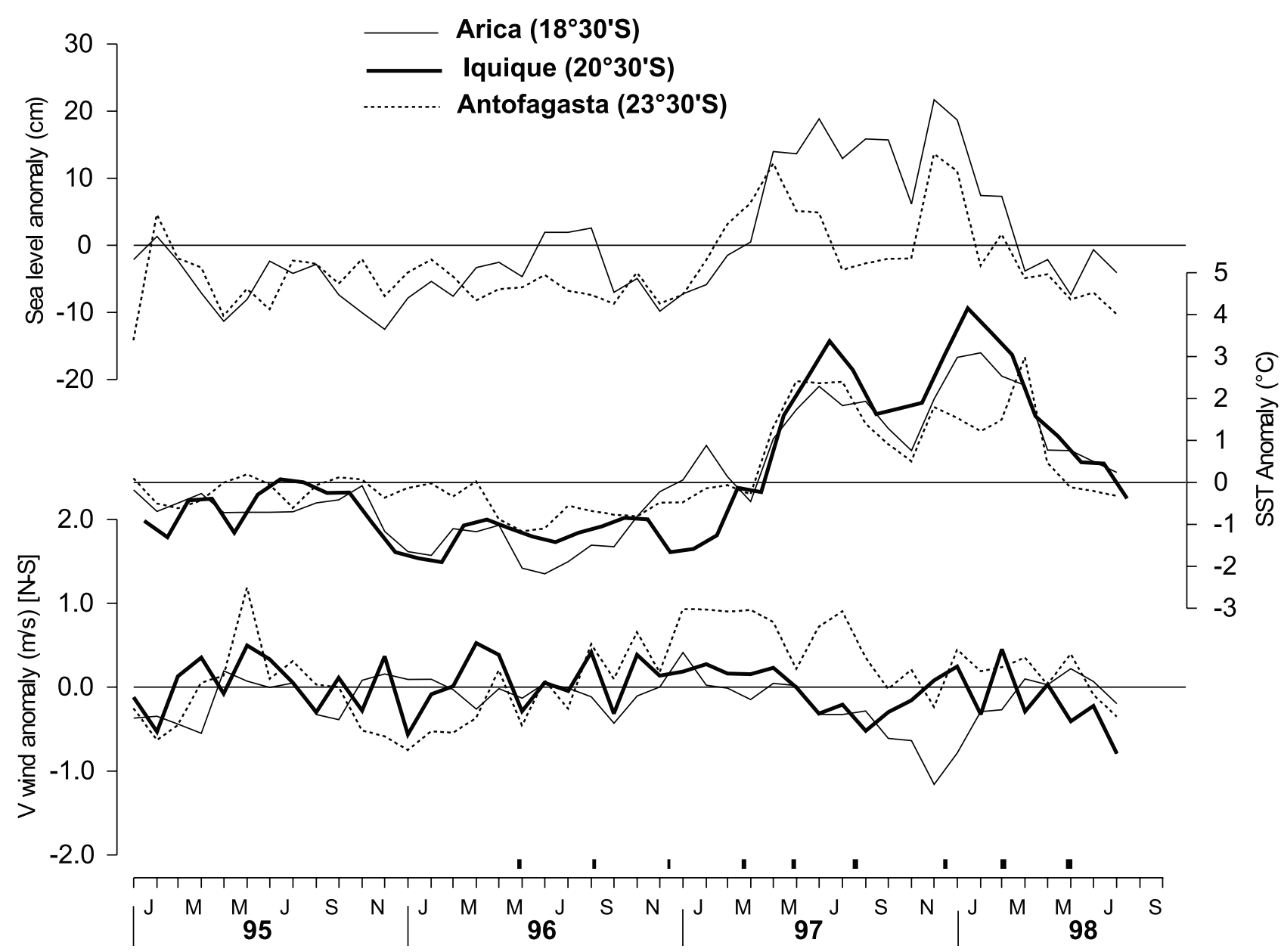

Figure 3. (continued)

tological monthly means of these variables [Blanco et al., 2001] were used here to form anomalies for the period between 1980 and 1998. These coastal time series place the hydrographic surveys in the context of the evolution between La Niña and El Niño conditions.

[14] The best oceanographic temporal context, however, is provided by a time series of vertical profiles of temperature, measured $\sim 10 \mathrm{~km}$ offshore of Iquique, in water over $500 \mathrm{~m}$ deep. Profiles are obtained every 2-4 weeks (more frequently when El Niño events are recognized). This invaluable time series of profiles has been maintained by the IFOP with assistance of personnel at the Universidad Arturo Prat (arrows in Figure 2b indicate sampling times).

\section{Results}

\subsection{Coastal Time Series}

[15] Monthly sea level anomalies from tide gauges located along the South American coast between the equator and $37^{\circ} \mathrm{S}$ for the period 1980-1998 (Figure 2a) do not allow analysis of phase propagation but clearly reveal the strength and extent of persistent sea level changes. The 1997-1998 and 1982-1983 El Niños were the dominant events in this period and were comparable in magnitude and duration. In each case, sea level anomalies exceeded $25 \mathrm{~cm}$ off Peru and northern Chile. In both events, two sea level maxima were separated by a relaxation period. Though sea level anomalies were $<10 \mathrm{~cm}$ between the equator and $37^{\circ} \mathrm{S}$, they were most pronounced north of $20^{\circ} \mathrm{S}$.
[16] Iquique $\left(20.5^{\circ} \mathrm{S}\right)$, in the center of our region of interest, is at the southern limit of the stronger and more persistent sea level response in 1997-1998 (Figure 2a). The time series of temperature profiles from Iquique is presented in Figure $2 \mathrm{~b}$ as a time-depth plot, using the same time axis. The two largest and most persistent disturbances in subsurface water properties occurred during the 1982-1983 and 1997-1998 El Niños. These data must be interpreted with some caution, given uneven sampling frequency. Sampling was unfortunately sparse during the 1982-1983 event with only nine cruises between January 1982 and December 1983. The 1997-1998 El Niño was better sampled, and 30 profiles were obtained between January 1997 and September 1998. The isotherms deepened with the two sea level maxima, in mid-1997 and again at the end of 1997 and beginning of 1998. In late 1997 the $15^{\circ} \mathrm{C}$ isotherm was deeper than $250 \mathrm{~m}$, its most extreme depth value on record.

[17] Monthly anomalies of adjusted coastal sea level, coastal SST, and winds for the 1980-1998 period at locations between $18^{\circ}-24^{\circ} \mathrm{S}$ are shown in Figure 3a. Sea level and SST anomalies from the northern and southern boundaries of the domain were greatest during the 1982-1983 and 1997-1998 events, as expected from Figure 2. However, the alongshore wind speed anomaly from Iquique only surpassed $1 \mathrm{~m} \mathrm{~s}^{-1}$ in 1982-1983: the anomaly was positive (increased upwelling) in late 1982 in the first period of high sea level and negative (decreased upwelling) in 1983 during the second maximum. Minimum average alongshore winds from the climatology (which occur in winter) are $2.5 \mathrm{~m} \mathrm{~s}^{-1}$ 

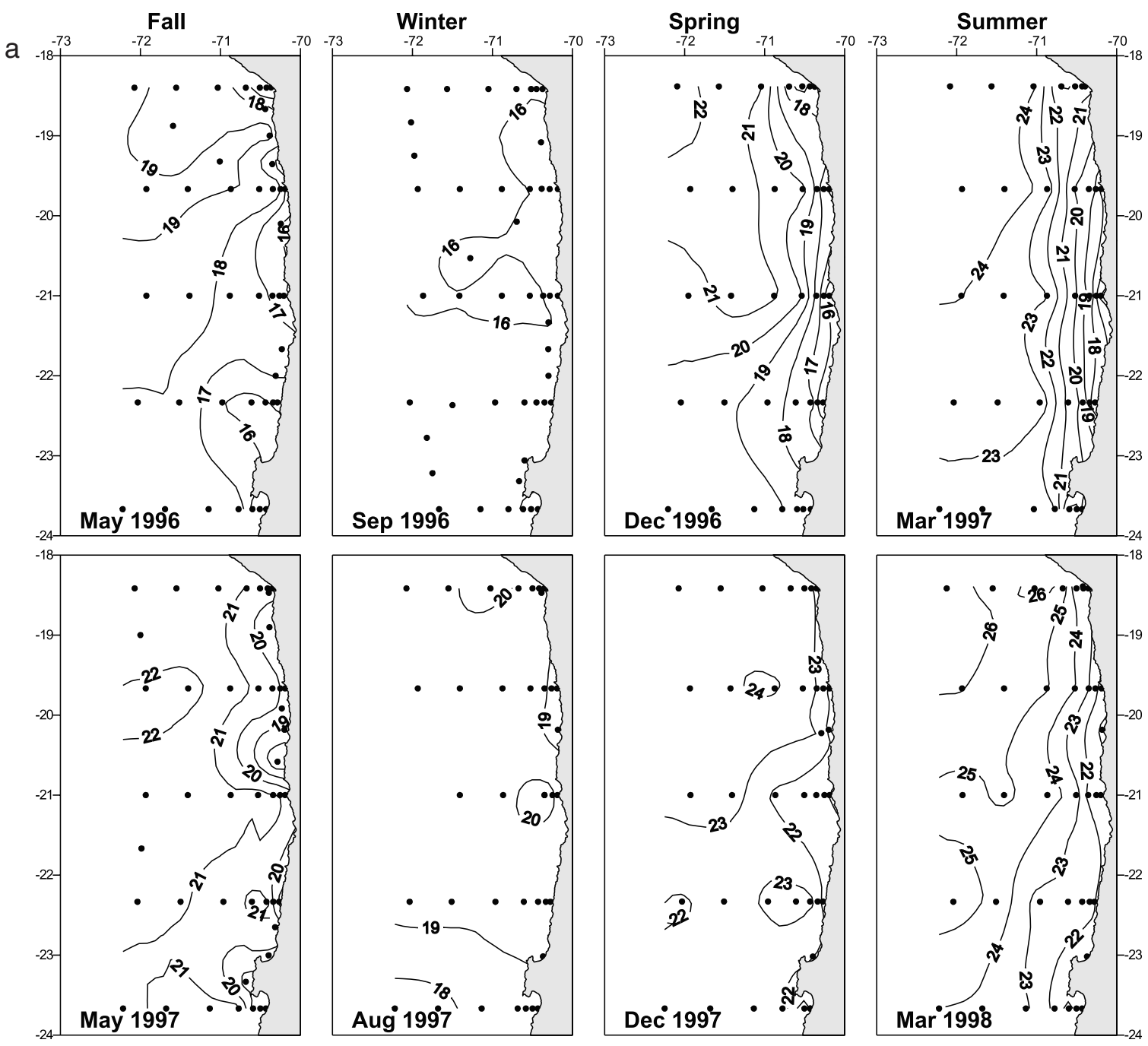

Figure 4. (a) SST from May 1996 through March 1998. (b) Anomalies of SST.

[Blanco et al., 2001], so anomalies below $2 \mathrm{~m} \mathrm{~s}^{-1}$ (Figure 3a) can enhance or reduce upwelling but cannot lead to downwelling.

[18] Although monthly averages cannot clearly distinguish the El Niño signal from intraseasonal variability owing to coastally trapped waves, we present them below to provide a context to the observed hydrographic changes. The expanded view of 19951998 (Figure 3b) indicates that although two distinct maxima occurred in SST at the three coastal stations, the relaxation between the peaks in sea level was not clear in the north (Arica). SST maxima were almost synchronous at the three locations and followed those of sea level by 1-2 months. Wind anomalies were moderately or weakly upwelling-favorable (in the south) at the onset of the first pulse in May 1997, then became weakly negative (decreased upwelling) in the northern half of the domain (Arica and Iquique) until the relaxation. Continued moderately reduced upwelling (negative wind anomalies) at Arica may explain the lack of a relaxation in sea level there. During the second pulse (December 1997 to January 1998) the decreased upwelling (negative wind anomalies) in the north is not sufficient to explain the onset of high sea levels and SSTs in May, although they may have enhanced the signal in the north after the first pulse and limited the relaxation. The normal summer winds during December 1997 to March 1998 in the southern part of the domain cannot account for the observed anomalies in sea level, SST, and isotherm depth during the second pulse. Comparable wind anomalies in preceding years (all of 1984 and early
1985 in Figure 3) were accompanied by moderate depressions in the $13^{\circ} \mathrm{C}$ isotherm and a smaller effect on the $15^{\circ} \mathrm{C}$ isotherm. These factors point to nonlocal forcing as the cause for the observed anomalies.

[19] Observations along the equator in the eastern Pacific reveal that pulses of high SSTs and depressed isotherms arrived off the coast of Ecuador in March 1997 (briefly), May-August 1997, and October 1997 to February 1998 [Chávez et al., 1998]. The timing of the pulses of high sea level and SST off northern Chile is consistent with an equatorial source in May-August and November-February.

[20] The best evidence for an equatorial connection comes from temperature profiles and tide gauge sea levels from Peru and Chile. Elevated daily sea levels (not presented) at the beginning of May 1997 propagated poleward from Baltra (at the equator) to Talcahuano $\left(37^{\circ} \mathrm{S}\right)$ in $\sim 11$ days, corresponding to an approximate phase velocity of $250-300 \mathrm{~km} \mathrm{~d}^{-1}$. By contrast to the transient event in March, sea levels remained persistently high for several months. The same timing in the depression of isotherms measured off Iquique at $20.5^{\circ} \mathrm{S}$ was observed in temperature profiles (not presented) from 1996 to 1998 off Ecuador at $2^{\circ} \mathrm{S}$ (La Libertad, data provided by Instituto Oceanografico de la Armada de Ecuador (INOCAR)) and Peru at $12^{\circ} \mathrm{S}$ (Callao, data provided by Instituto del Mar de Peru (IMARPE)). All three time series show two pulses separated by a relaxation, although the pulses lasted somewhat longer at $2^{\circ} \mathrm{S}$ [Comisión Permanente del Pacif- 

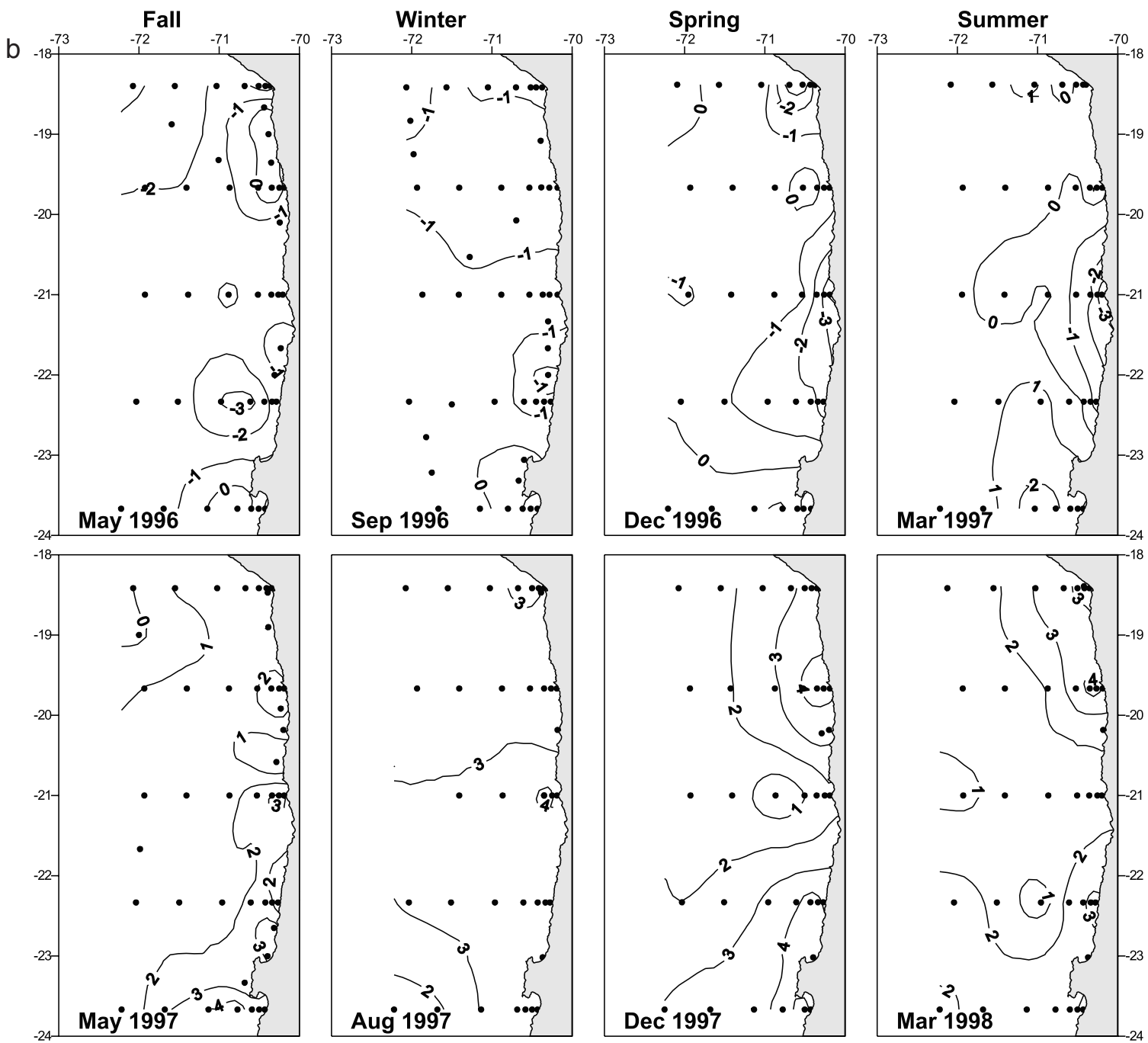

Figure 4. (continued)

ico Sur (CPPS), 1999]. A similar sudden warming was also observed in early May 1997 in a bay north of Antofagasta, but the time series (to August 1997) ended before the relaxation and second pulse [Escribano, 1998]. These signals followed those at the equator [Chávez et al., 1998], supporting the connection to equatorial events. These data illustrate the need for time series of subsurface conditions to facilitate interpretation of surface signals (SST and sea level) that may respond rapidly to local forcing. The hydrographic cruises provide additional evidence on the role of CTWs.

\subsection{Hydrographic Cruises Prior to and During the EI Niño: May 1996 to March 1998}

[21] Surface fields of temperature and salinity between May 1996 and March 1998 are shown in Figures 4 and 5 along with their associated anomalies. Figures 2 and 3 provide a temporal context for the surveys. The first three cruises (May, September, and December 1996) occurred during the low sea level, cold period (La Niña) prior to El Niño conditions, while the March 1997 cruise corresponds to transitional sea levels and coastal SSTs. May and December 1997 surveys were made during the first and second pulse of high sea level, respectively, and August 1997 was either near the end of the first pulse in sea level or in the relaxation period. In March 1998, sea levels at Antofagasta had returned to normal, although sea levels at Arica and coastal SST values throughout the region were still high. By May 1998, sea levels and SSTs were again below the climatological mean, similar to those of 1996 prior to the onset of El Niño.

[22] The seasonal progression of SST patterns (Figure 4a) from May 1996 to March 1997 was approximately normal: the offshore gradient disappeared, and the north-south gradient weakened in winter (September 1996). Both were reestablished in spring and intensified in summer (December 1996 to March 1997). However, the surface was generally cooler $\left(-1^{\circ}\right.$ to $\left.-3^{\circ} \mathrm{C}\right)$ (Figure $\left.4 \mathrm{~b}\right)$. The temperature anomalies were consistent with less equatorial water (STW) offshore (e.g., in the northeast in May 1996) and stronger upwelling in the center of the domain (maximum in December 1996 and March 1997). In March 1997 the $23^{\circ}$ and $24^{\circ} \mathrm{C}$ isotherms extended farther south than climatology, leading to a weak positive SST anomaly and a stronger cross-shelf gradient than usual.

[23] May and August $1997 \mathrm{SST}$ were $\sim 3^{\circ} \mathrm{C}$ warmer than the previous year. By May 1997, offshore SST exceeded $21^{\circ} \mathrm{C}$ throughout the domain (Figure $4 \mathrm{a}$ ), creating positive anomalies of $1-3^{\circ} \mathrm{C}$ in the south (Figure $4 \mathrm{~b}$ ). Typical fall upwelled water was absent except at $21.5^{\circ} \mathrm{S}$, so coastal anomalies were $\sim 1^{\circ}-2^{\circ} \mathrm{C}$. The disappearance of the meridional gradient led to stronger SST anomalies in the south. August 1997 presented the usual winter homogeneous SST field north of $23^{\circ} \mathrm{S}$ but with higher temperatures $\left(2^{\circ}-3^{\circ} \mathrm{C}\right)$. In December 1997 the usual spring offshore gradient was essentially absent except at $21^{\circ} \mathrm{S}$, consistent with ongoing upwelling. SST anomalies ranged from $1^{\circ}$ to $2^{\circ}-4^{\circ} \mathrm{C}$. The gradient 

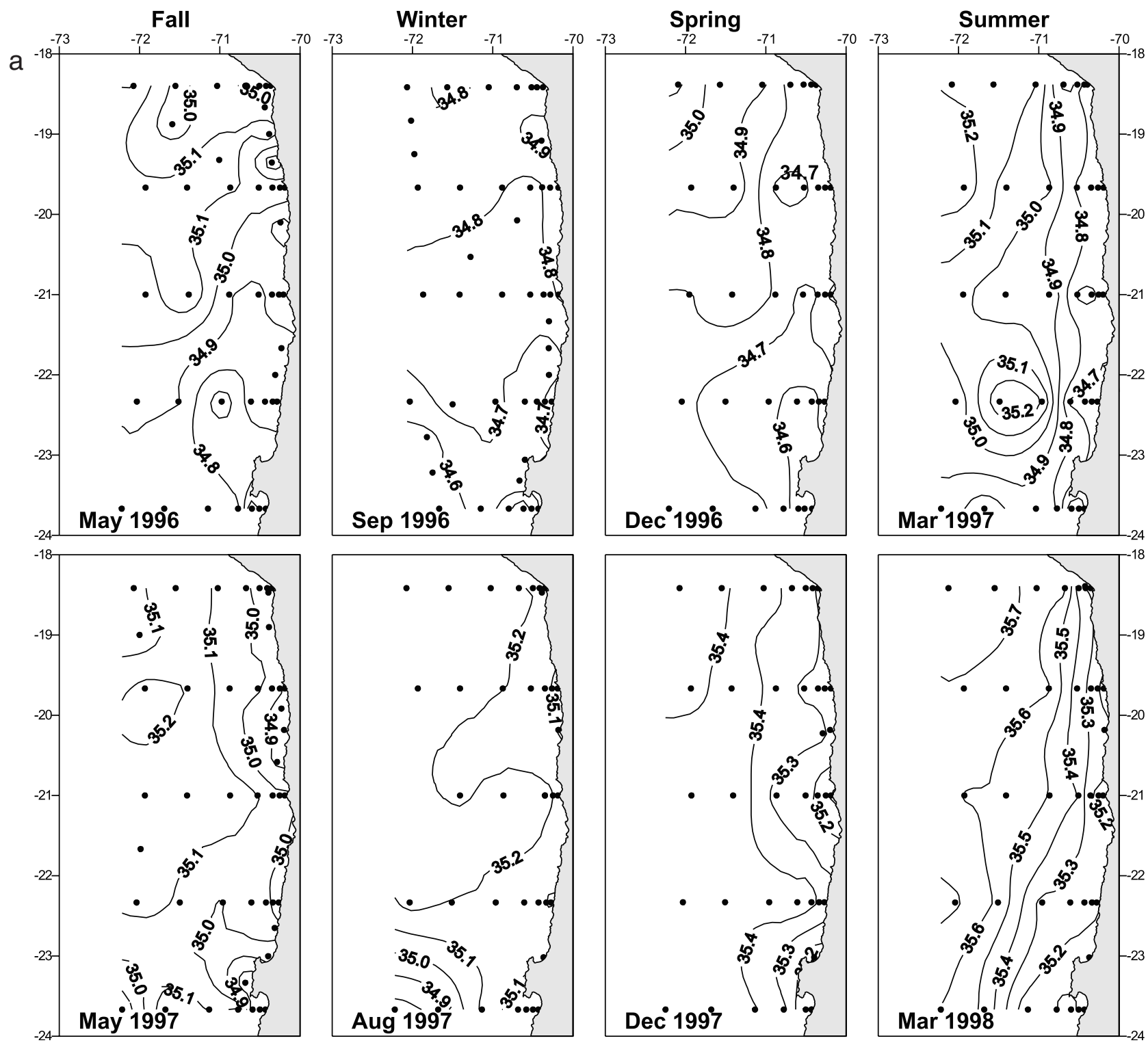

Figure 5. (a) Surface salinity from May 1996 to March 1998. (b) Anomalies of surface salinity.

increased in March 1998 in response to offshore heating and coastal upwelling and the total area of anomalously warm water was reduced. Anomalies were minimum at $21^{\circ} \mathrm{S}$ but remained at $2{ }^{\circ} \mathrm{C}$ or more to the south and north.

[24] Climatological surface salinity patterns are similar to those of SST [Blanco et al., 2001]. From May 1996 through March 1997 the seasonal progression was normal (Figures $5 \mathrm{a}$ and $5 \mathrm{~b}$ ) with generally lower salinity values (anomalies of $0.1-0.3$ practical salinity units (psu)). The characteristic meridional salinity gradient [Blanco et al., 2001] was observed, but the cross-shelf gradient was weak. Positive (in May 1996) or weak negative anomalies occurred close to the coast. Negative anomalies were strongest offshore (maximum in September 1996), consistent with the decreased influence of STW (similar to that inferred from the cool SST pattern).

[25] The upwelling-induced cross-shelf gradient was close to normal in May 1997, but the salinity values were slightly above climatology, leading to positive anomalies $(<0.1 \mathrm{psu})$ in most places. This cruise revealed a transition from cool and fresh to moderately warm and salty anomalies. The typical uniform winter pattern in August 1997 was restricted to the north; a meridional front near $21^{\circ} \mathrm{S}$ and anomalies of the order of $0.2-0.3 \mathrm{psu}$ suggested increased poleward transport of STW. Upwelling reestablished the offshore gradients in spring and summer (December 1997 and March 1998), but values remained anomalously high by $0.2-0.6$ psu. Maximum anomalies occurred in the south in December 1997, reflecting the reduced north-south gradient.

[26] Cross-shelf transects of the vertical distribution of temperature, salinity, and oxygen at $21^{\circ} \mathrm{S}$ (Pta. Lobos in Figure 1) and the anomalies for temperature and salinity changed significantly during the study period (Figures 6-8). From May 1996 to March 1998 , isotherms shoaling toward the coast indicate near-surface upwelling. From May to December 1996 the surface mixed layer was exceptionally shallow, and temperatures in the upper $100 \mathrm{~m}$ were lower than climatology (Figure 6). The $13^{\circ} \mathrm{C}$ isotherm was shallower during this period than its usual upper limit of $100 \mathrm{~m}$ [Blanco et al., 2001]. This shoaling of the thermocline led to maximum negative anomalies of $2-3^{\circ} \mathrm{C}$ at $30-50 \mathrm{~m}$ (Figure $6 \mathrm{~b}$ ), where the vertical temperature gradient is normally maximum. The poleward undercurrent, indicated by spreading isotherms between $12^{\circ}$ and $13^{\circ} \mathrm{C}$, was stronger than normal during May 1996 , creating weak positive anomalies below $200 \mathrm{~m}$. The temperature structure below $100 \mathrm{~m}$ was similar to the climatology between September 

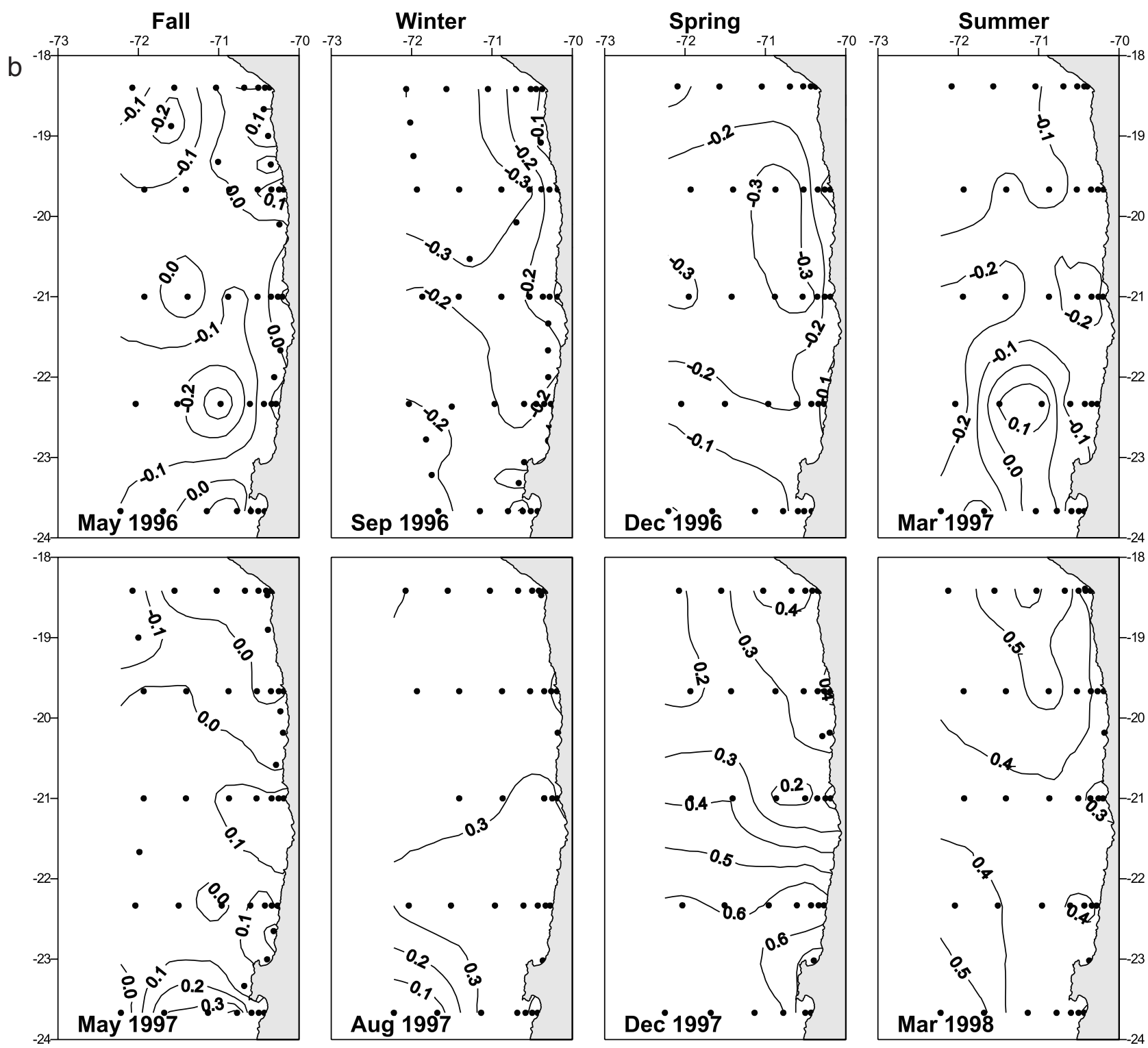

Figure 5. (continued)

1996 and March 1997, as indicated by anomalies of $<1^{\circ} \mathrm{C}$. In March 1997 a stronger and deeper thermocline offshore led to warm surface anomalies $\left(>2^{\circ} \mathrm{C}\right)$.

[27] By the time of the first sea level peak in May 1997, the subsurface thermal structure had changed substantially. The $13^{\circ} \mathrm{C}$ isotherm reached $200 \mathrm{~m}$ at the coast, though it was close to normal $150 \mathrm{~km}$ offshore. The undercurrent appeared to be strong, with maximum isotherm slopes $\sim 100 \mathrm{~km}$ from the coast. Anomalies of over $1^{\circ} \mathrm{C}$ extended to $500 \mathrm{~m}$ inshore of $100 \mathrm{~km}$. The anomaly at 40 $\mathrm{m}$ depth $\left(2^{\circ}-3^{\circ} \mathrm{C}\right)$ was greater than at the surface (Figure $\left.4 \mathrm{~b}\right)$. During the relaxation between pulses (August 1997), the isotherms were level, and positive anomalies $\left(2^{\circ}-3^{\circ} \mathrm{C}\right)$ were restricted to the upper $100 \mathrm{~m}$ (Figure 3b). December 1997, during the second sea level maximum, presented the most extreme anomalies at depth. The undercurrent was relatively strong, with steepest isotherm slopes at $\sim 100-200 \mathrm{~m}$ depth within $100 \mathrm{~km}$ from the coast. Near-shore temperature anomalies surpassed $2^{\circ}-3^{\circ} \mathrm{C}$ to $300 \mathrm{~m}$. Offshore stratification was enhanced at the thermocline $(30-50 \mathrm{~m})$, creating anomalies of $3^{\circ}-4^{\circ} \mathrm{C}$. In March 1998 the undercurrent was reduced or absent, and the entire water column below $100 \mathrm{~m}$ was $2{ }^{\circ} \mathrm{C}$ cooler than in December. Anomalies below $200 \mathrm{~m}$ had reversed to become weakly negative, although high positive anomalies $\left(4^{\circ}-5^{\circ} \mathrm{C}\right)$ persisted in the upper $100 \mathrm{~m}$. Generally, the intensity and extent of the subsurface anomalies did not correspond directly to the those at the surface (Figures $4 \mathrm{~b}$ and $6 \mathrm{~b}$ ).

[28] The salinity transects, although generally similar to those of temperature, help clarify water mass distributions (Figure 7a). In May 1996 the salty STW (here only slightly over 35.0) could be distinguished at the surface in the offshore region. SAW (34.4-34.5) was found underneath the STW offshore, while relatively salty ESSW (34.9) was found near the coast between 100 and $300 \mathrm{~m}$ in the undercurrent and upwelling into the upper $50 \mathrm{~m}$. From May to December 1996, both STW and SAW were fresher than climatology, leading to negative salinity anomalies of up to $0.4-0.5$ at $30-50 \mathrm{~m}$ (Figure $7 \mathrm{~b}$ ). The anomalously fresh intrusion of SAW continued through December of 1996, almost reaching the coast in the upper $100 \mathrm{~m}$. In September and December 1996, no STW water was evident above SAW. The salinity maximum of the undercurrent in December 1996 was weaker than the climatological spring field, producing negative 


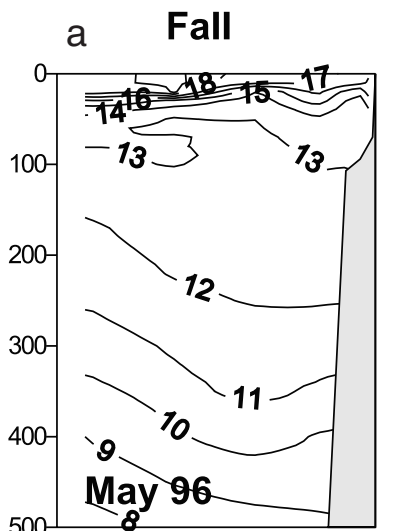

Winter

Spring

Summer
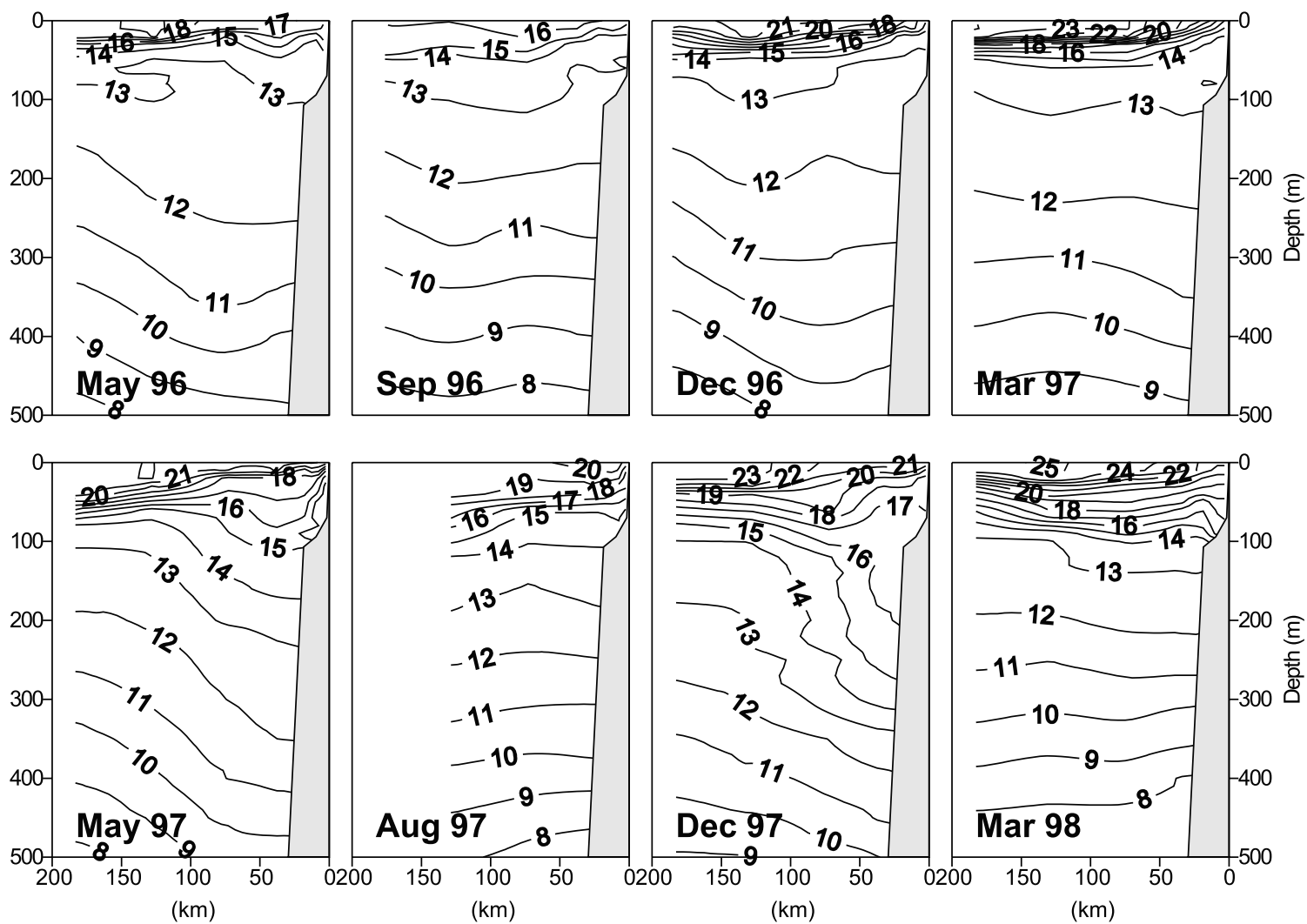

b Fall

Winter

Spring

Summer
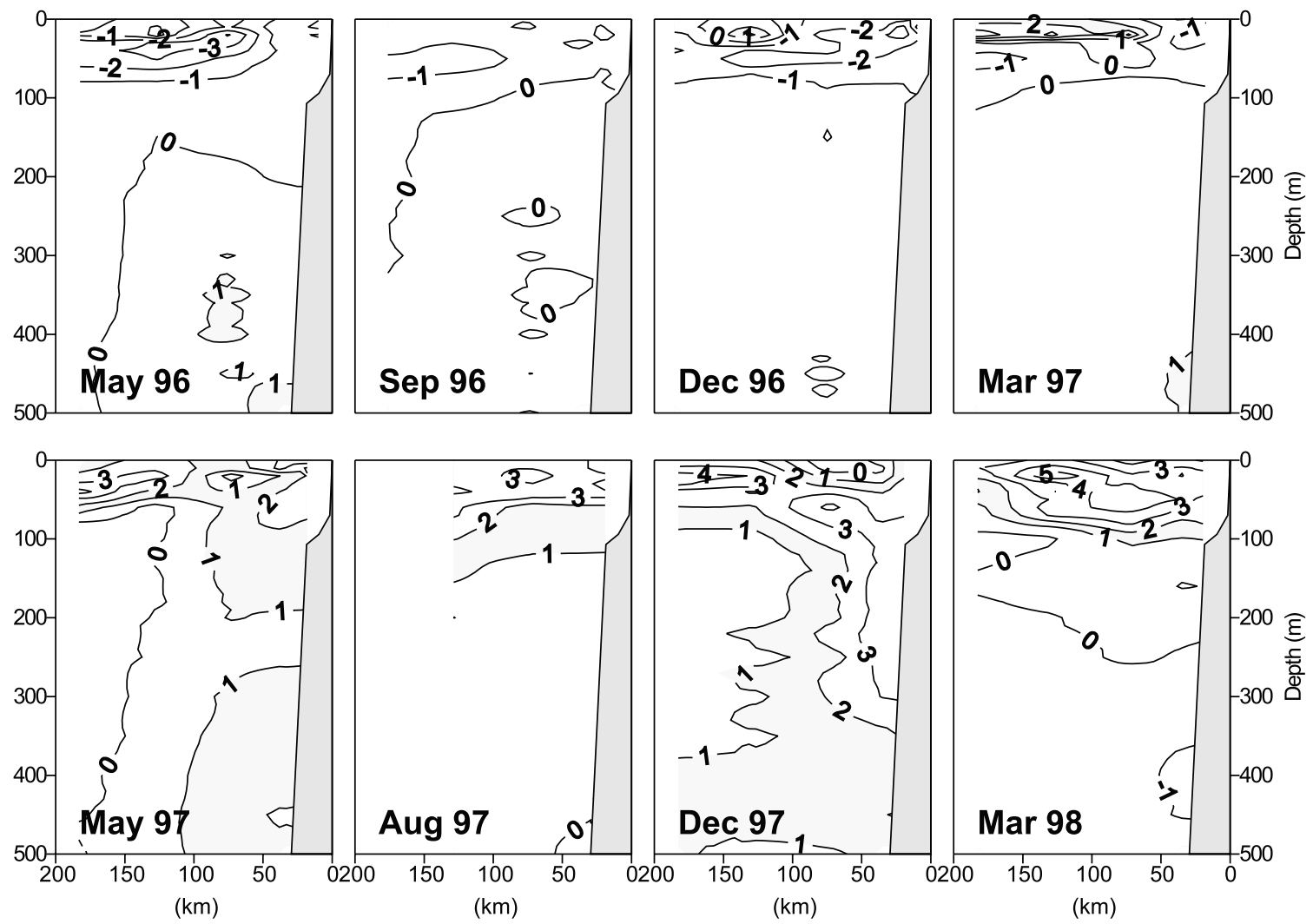

Figure 6. (a) Cross-shelf temperature distribution along the transect at $21^{\circ} \mathrm{S}$ (Pta. Lobos) from May 1996 to March 1998. (b) Cross-shelf vertical distribution of temperature anomalies. 

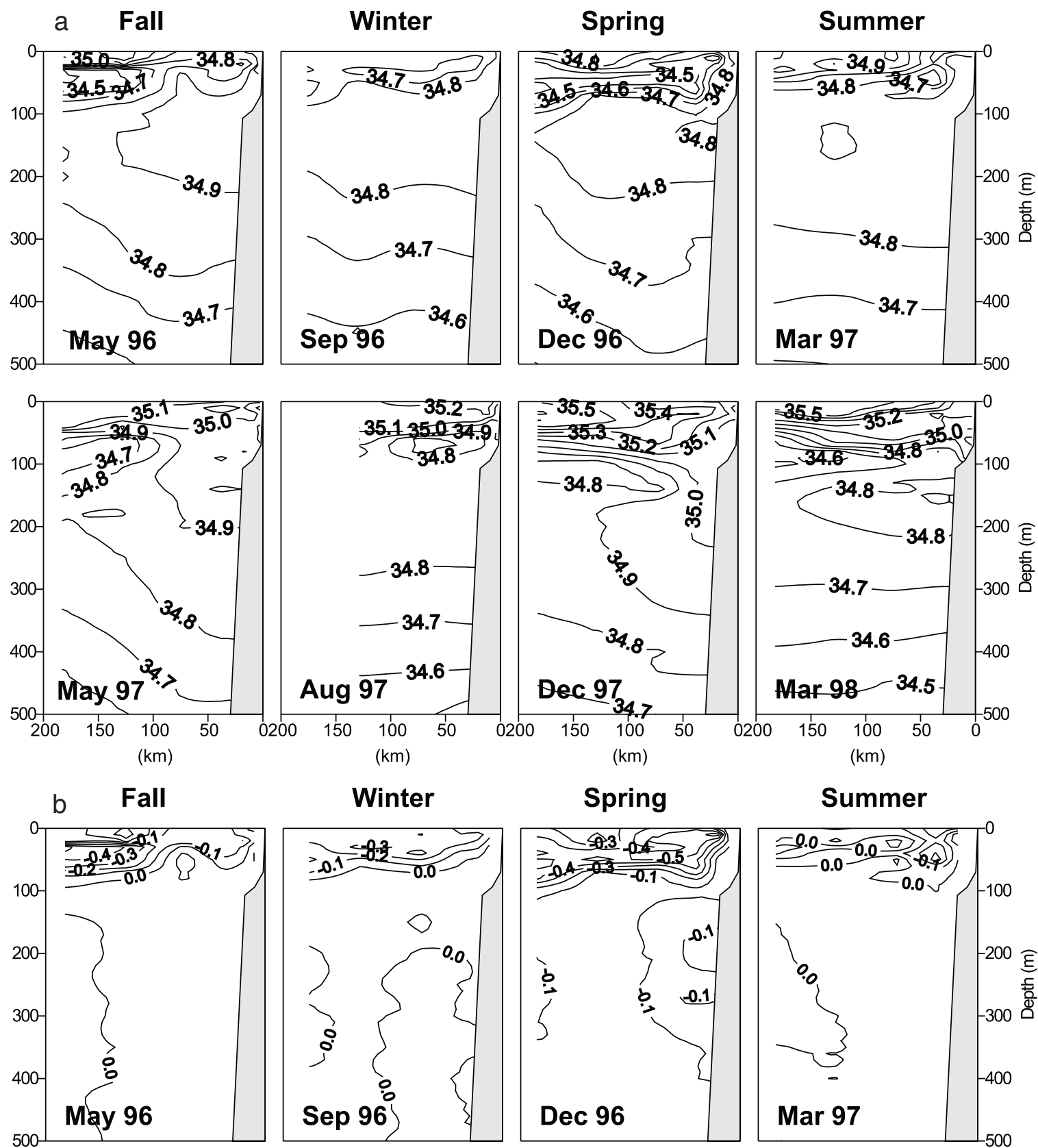

Winter

Spring
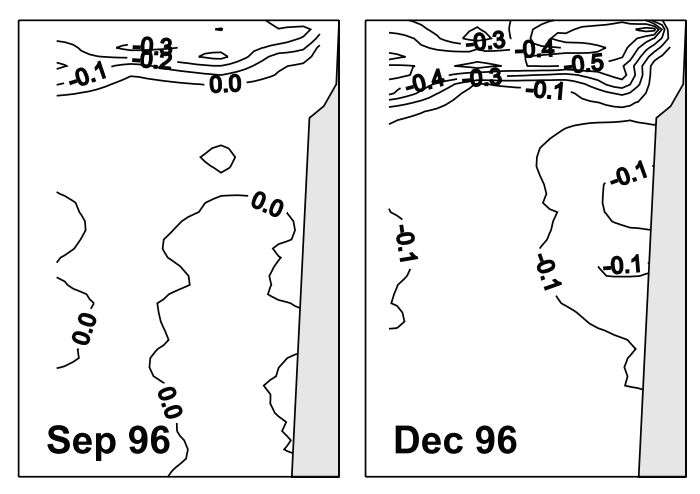

Summer
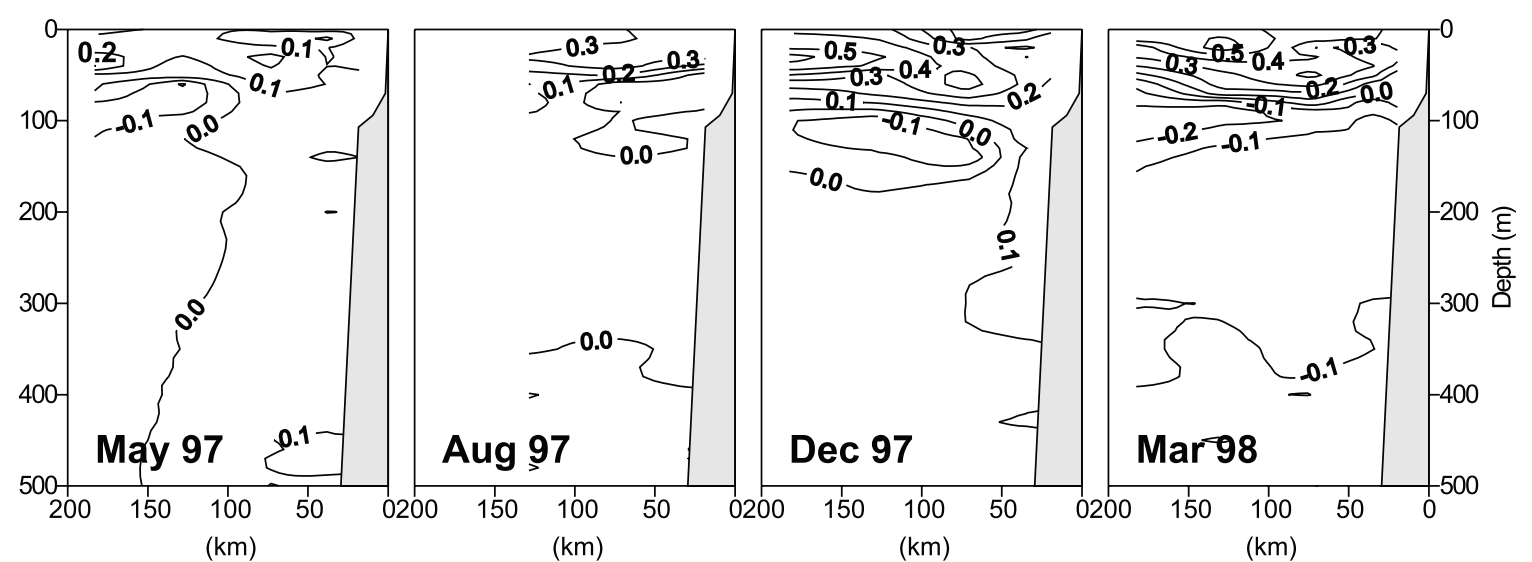

Figure 7. (a) Cross-shelf vertical salinity distribution along $21^{\circ} \mathrm{S}$ from May 1996 to March 1998. (b) Cross-shelf vertical distribution of salinity anomalies. 
Fall
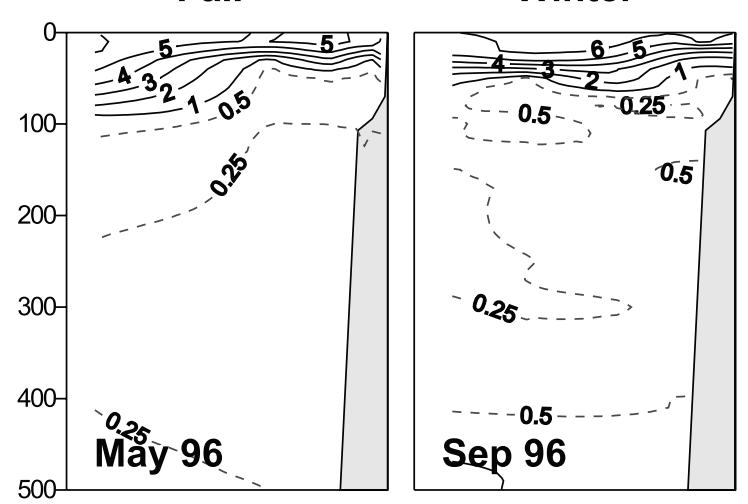

Spring

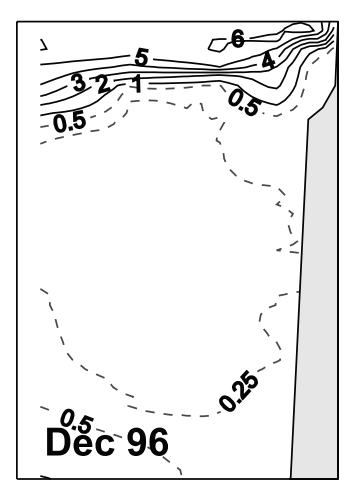

Summer

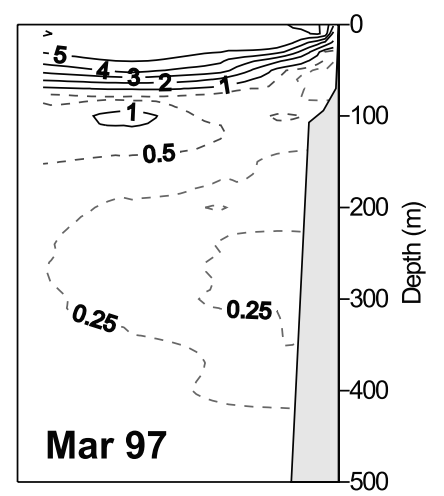

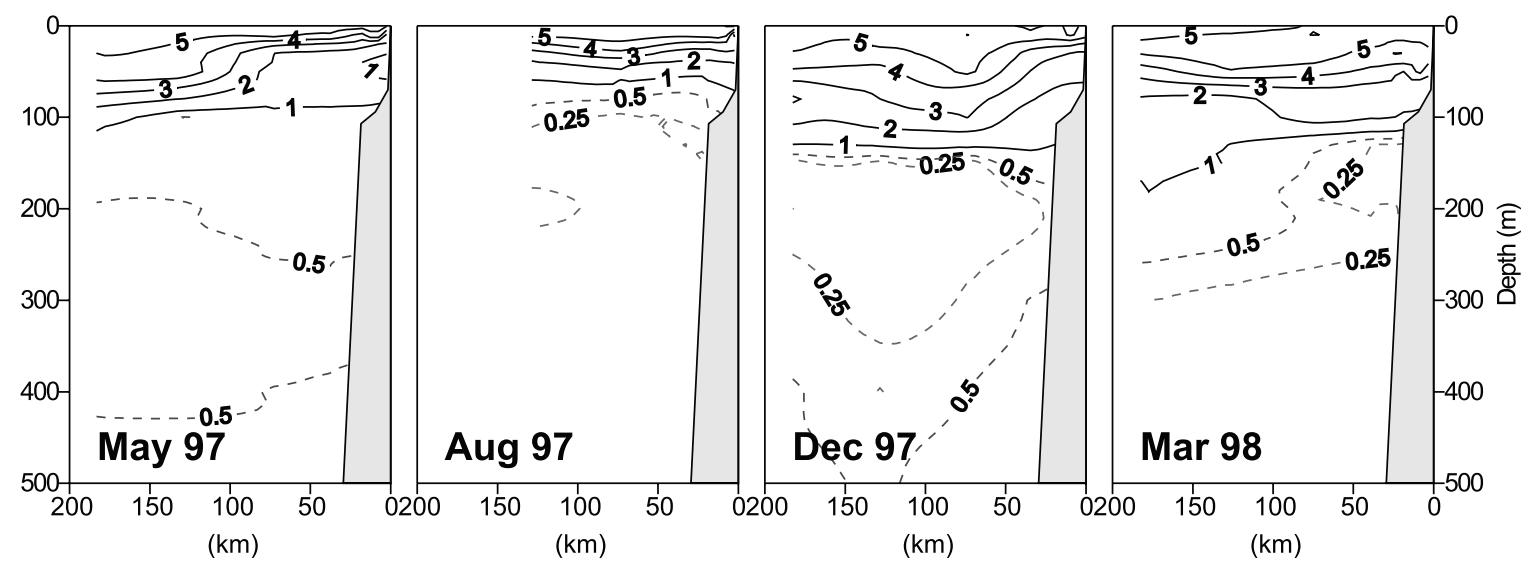

Figure 8. Cross-shelf vertical distribution of oxygen concentrations along $21^{\circ} \mathrm{S}$ from May 1996 to March 1998.

salinity anomalies next to the coast at depth. In March 1997, salinities were close to summer climatology with patchy and weak negative anomalies in the upper $100 \mathrm{~m}$.

[29] In May 1997, anomalies over most of the water column changed from weakly negative to positive, concurrent with those of subsurface temperature (Figures 6 and 7). An intensified and shallow undercurrent brought saltier ESSW (34.9-35.0) into the region within $100 \mathrm{~km}$ of the coast, while a deep layer of STW (>35.0) extended throughout the transect. The fresh tongue of SAW in the west was depressed by the increased volume of STW, and its eastward progression was limited by the undercurrent. Anomalies were positive in the upper $50 \mathrm{~m}$ through the transect and within $125 \mathrm{~km}$ of the coast to $500 \mathrm{~m}$ depth, while negative anomalies were found offshore at 75-100 m (Figure 8b). During the relaxation in August 1997 the surface layer was deeper and more saline, creating positive anomalies of 0.3 psu in the upper 50 m. As in temperature, December 1997 presented the greatest changes at depth, with positive salinity anomalies to $400-500 \mathrm{~m}$ near the coast and to $100 \mathrm{~m}$ offshore. In December 1997 a tongue of STW (35.5) penetrated the upper $50 \mathrm{~m}$, surfacing within $50 \mathrm{~km}$ of the coast in March 1998. Maximum anomalies (0.5-0.6) were observed offshore of $100 \mathrm{~km}$ in the upper $50 \mathrm{~m}$ in December 1997 and March 1998. Near-shore upwelling of fresher water reduced the anomalies to $0.2-0.3$. SAW was present at greater depths than usual in the offshore half of the transect, creating negative anomalies $(0.1-0.2)$ slightly below $100 \mathrm{~m}$ depth. In March 1998 the upper $80 \mathrm{~m}$ were anomalously saline (STW). Below this the water column was fresher than climatology because of a decrease in the undercurrent.

[30] The climtological seasonal variation in oxygen concentrations in the upper $100 \mathrm{~m}$ is weak [Blanco et al., 2001]. Values surpass $5 \mathrm{~mL} \mathrm{~L}^{-1}$ in a $50 \mathrm{~m}$ deep surface layer $400 \mathrm{~km}$ offshore and shoaling to the surface at the coast. The $0.5 \mathrm{~mL} \mathrm{~L}^{-1}$ isopleth is found at $125-150 \mathrm{~m}$ offshore and shoals to $75-100 \mathrm{~m}$ at the coast; this slope increases slightly in spring and summer. Minimum oxygen concentrations $\left(<0.5 \mathrm{~mL} \mathrm{~L}^{-1}\right)$ occur between 125 and $450 \mathrm{~m}$ in the ESSW, carried by the poleward undercurrent. From May 1996 to March 1997 the vertical gradient in oxygen concentration above $100 \mathrm{~m}$ was enhanced because of the combined effect of high subsurface oxygen, associated with onshore penetration of SAW, and an intensified undercurrent (Figure 8). The $0.5 \mathrm{~mL} \mathrm{~L}^{-1}$ isopleth was above $100 \mathrm{~m}$ owing to the increased volume of lowoxygen ESSW.

[31] In May and December 1997 and March 1998 the surface layer of high-oxygen concentrations deepened to $100-150 \mathrm{~m}$, as STW and SAW extended from offshore to the coast. In August 1997, during the relaxation between pulses, the low-oxygen concentration core shoaled, and the upper layer of high-oxygen concentrations thinned to $<100 \mathrm{~m}$. During the El Niño period (May 1997 to March 1998) the vertical gradient was weaker than the previous year as both STW and SAW overlaid the ESSW.

[32] Temperature-salinity $(T-S)$ diagrams from the transect at $21^{\circ} \mathrm{S}$ from each cruise summarize the relative influence of the different water masses (Figure 9). Between May and December 1996, there was a much stronger influence of SAW (the subsurface relative minima in salinity) and a weaker influence of STW than is usually found at this latitude [Blanco et al., 2001]. The seasonal progression resembled more closely that normally observed farther north in sections off Antofagasta at $23^{\circ} \mathrm{S}$ [Blanco et al., 2001]. There was virtually no STW in September and December 1996. The T-S characteristics of March 1997 represent a transition between La Niña and El Niño conditions and resembled climato- 


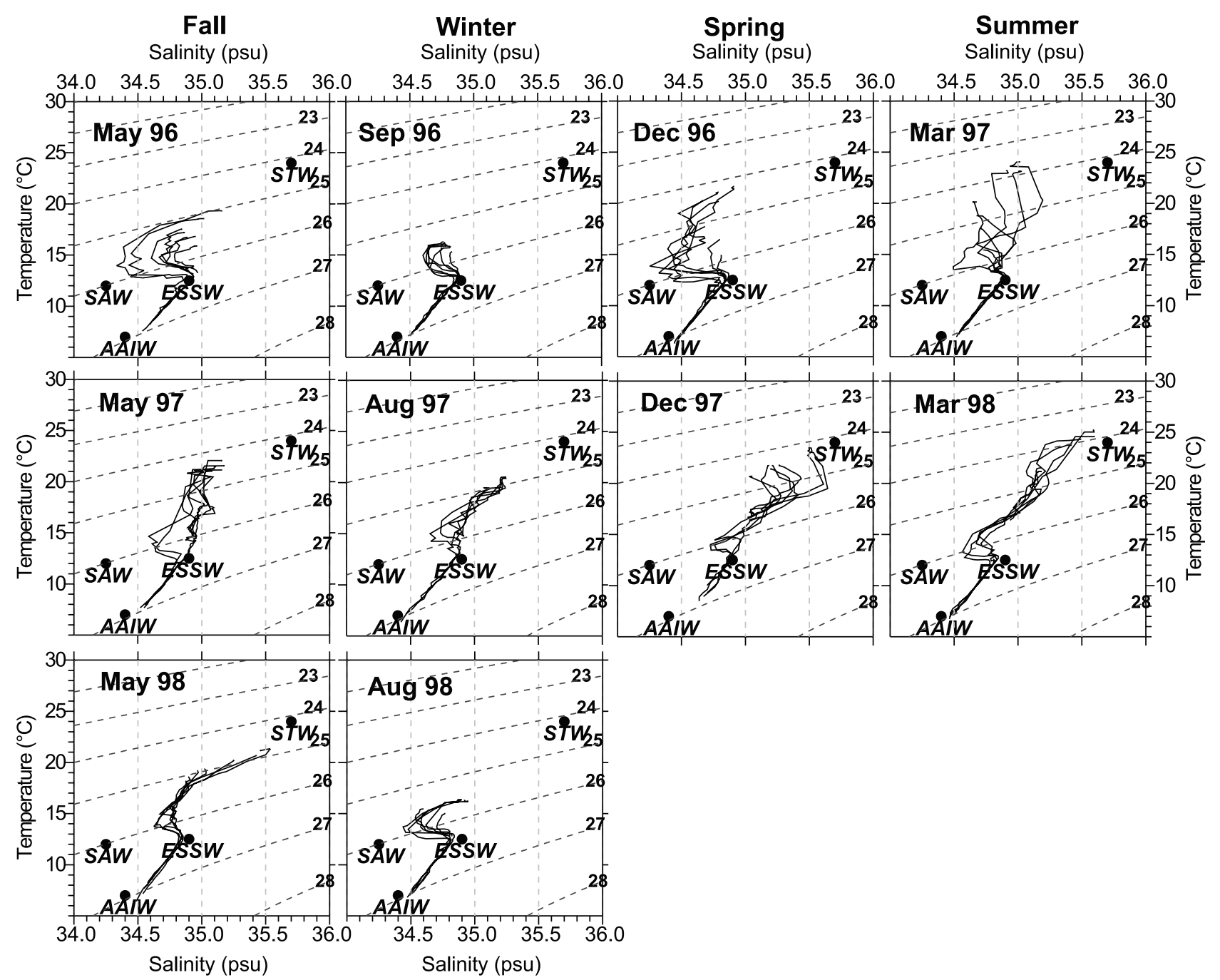

Figure 9. Temperature-salinity diagrams for all stations along $21^{\circ} \mathrm{S}$ from May 1996 to August 1998.

logical values at this latitude, except for a stronger influence of SAW in the most offshore profiles and a warmer, more saline upper layer.

[33] In May 1997 the $T-S$ characteristics of the upper layer reflect the influence of STW and resembled the climatological $T-S$ characteristics from Arica to the north. SAW remained (as a middepth minimum in salinity) through March 1998 in the offshore profiles. Although salinity values corresponded to SAW at this latitude, the temperature was higher and the thickness of the layer (temperature range) was less than in the seasonal climatology [Blanco et al., 2001]. From May 1997 the upper part of the water column became progressively warmer and more saline. By March 1998 the $T-S$ values were close to those of pure STW and much higher than those of the modified STW usually found in this region. The ESSW was warmer and shallower than usual from May 1997 to March 1998. The characteristic salinity maximum due to ESSW disappeared as the salinity increased in the upper part of the water column. Results for May and August 1998 are discussed in section 3.3.

[34] Geopotential anomalies (scaled like dynamic heights) at the surface and at $200 \mathrm{dbar}$ relative to 500 dbar portray surface and subsurface $(200 \mathrm{~m})$ circulation, respectively (Figures 10a and 10b). Surface flow was primarily equatorward from May 1996 to March 1997. Equatorward flow was stronger in the north than in the south during May 1996 and March 1997. In September and December 1996, equatorward flow within $100 \mathrm{~km}$ of the coast was stronger and more uniform throughout the study region than in the climatology [Blanco et al., 2001]. This is consistent with the colder, fresher water in the surface layers (more SAW, less STW). During the same period (May 1996 through March 1997), flow at $200 \mathrm{~m}$ was primarily poleward, strongest in May 1996 and March 1997 (Figure 10b). The increased poleward flow in March 1997 corresponds to the seasonal progression, as the undercurrent maximum is in summer [Blanco et al., 2001]. Stronger poleward flow in May 1996 is consistent with the increased thickness of the salty undercurrent (Figures 6a, 7a, and 9).

[35] In both May and December 1997 (the two sea level peaks), strong poleward currents were found at both the surface and at $200 \mathrm{~m}$ (Figure 10), with onshore flow in the north of the domain. This is consistent with the increased volume of STW at the surface and with the subsurface layer of SAW stretching onshore in the north. In contrast, the relaxation period (August 1997) presented equatorward flow in the center of the domain, onshore flow in the south, and offshore flow in the north. The currents in the upper $200 \mathrm{~m}$ switched from relatively baroclinic (opposite directions at the surface and at $200 \mathrm{~m}$ ) during the year preceding the El Niño, to relatively barotropic (currents in the same direction) during the sea level pulses and immediately following them. In March 1998 the flow was strongly equatorward in the northern and southern parts of the domain, and there was no poleward component, although the climatological undercurrent maximum is in summer. This is consistent with weak 

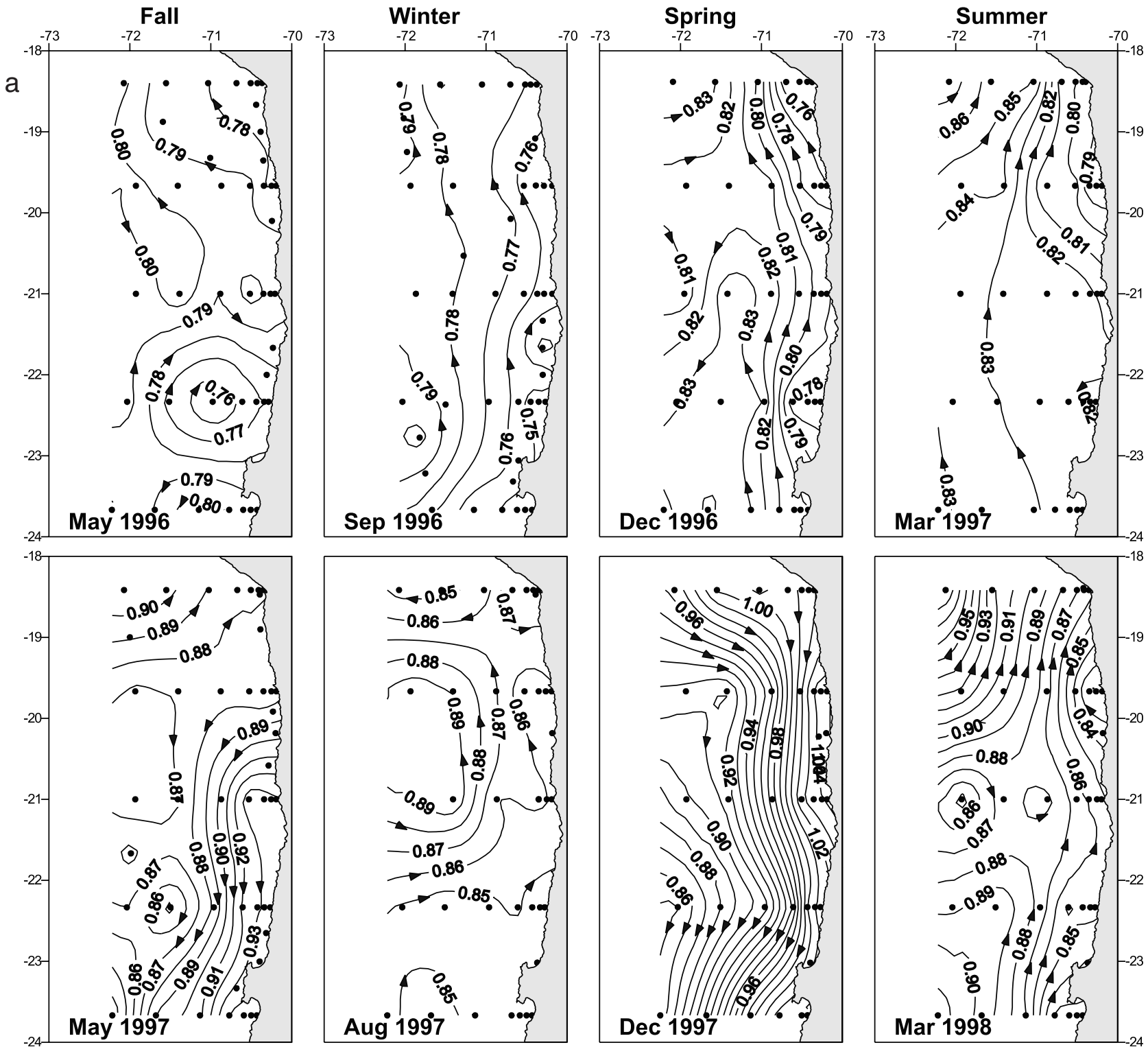

Figure 10. (a) Geopotential anomaly at 0/500 dbar from May 1996 to March 1998. (b) Geopotential anomaly at $200 / 500$ dbar.

ESSW, collapse of the oxygen minimum, and minimum crossshelf slope of isotherms and isohalines.

[36] Temporal evolution of the vertical structure of alongshore velocity can be visualized in offshore sections of geostrophic velocity relative to 500 dbar (Figure 11). Flow in the year prior to the El Niño was generally weaker and more complex compared to that during the two pulses of high sea level in May and December 1997. May 1996 and March 1997 presented large vertical shear. Below $100 \mathrm{~m}$ the flow was relatively barotropic, with alternating cross-shelf bands of equatorward and poleward flow caused by eddies and meanders. During May and December 1997, strong poleward flow extended throughout the water column, with subsurface maxima of 20-35 $\mathrm{cm} \mathrm{s}^{-1}$ centered at $100 \mathrm{~m}$. Following the poleward pulses, flow was again more complex and generally equatorward with maxima (relative to $500 \mathrm{~m}$ ) of $\sim 10 \mathrm{~cm} \mathrm{~s}^{-1}$.

\subsection{Hydrography After the El Niño: May 1998}

[37] By May 1998, alongshore winds, coastal sea levels, and SSTs were near climatological seasonal mean values (Figure 3).
The eastern equatorial Pacific was engaged in a rapid transition to La Niña conditions [Neelin and Latif, 1998]. During the May 1998 cruise, SST and surface salinity adjacent to the coast approached normal seasonal values (anomalies $<1^{\circ} \mathrm{C}$ and $\sim 0.1 \mathrm{psu}$ ) owing to coastal upwelling (Figure 12). SST was close to climatology in most of the region, but offshore salinity and nearshore salinity at $19.7^{\circ} \mathrm{S}$ were still very high $(35.4-35.6)$. The largest anomalies $\left(2^{\circ} \mathrm{C}\right.$ and $\left.0.5 \mathrm{psu}\right)$ occurred $20-40 \mathrm{~km}$ offshore at $19.7^{\circ} \mathrm{S}$. The surface and subsurface geopotential fields indicated that this patch was associated with strong onshore flow of warm, salty water at $20^{\circ}-21^{\circ} \mathrm{S}$ around an anticyclonic eddy (Figure 12).

[38] Cross-shelf sections of temperature, salinity, temperature anomaly, salinity anomaly, oxygen, and alongshore geostrophic velocity at $21^{\circ} \mathrm{S}$ are presented in Figure 13 for comparison to Figures 6-9. Unfortunately, these sections sample the southern edge of the eddy in Figure 12. The associated salinity anomalies do not extend below $30 \mathrm{~m}$ depth. Similar sections at $19.7^{\circ} \mathrm{S}$ from the same survey (not presented) which sampled the core of the eddy revealed a surface layer of STW $200 \mathrm{~km}$ offshore, leading to strong salinity anomalies extending to $100 \mathrm{~m}$ depth. At $21^{\circ} \mathrm{S}$, temper- 

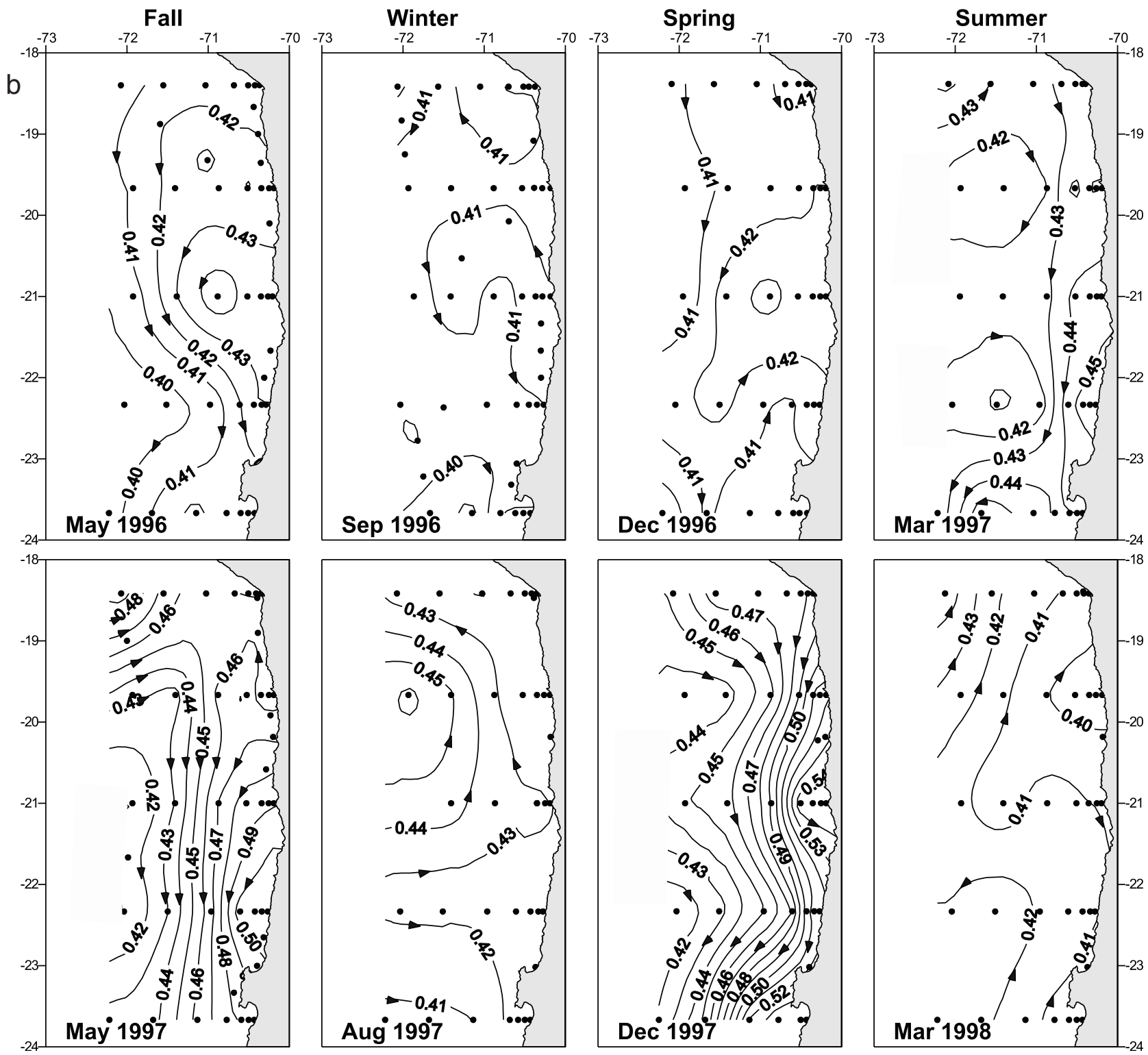

Figure 10. (continued)

atures below $50 \mathrm{~m}$ were close to the fall average conditions, while salinities and temperatures between 25 and $50 \mathrm{~m}$ were fresh and cool (Figure 13), likely of SAW origin, perhaps carried onshore along the southern flank of the anticyclonic eddy. The poleward flow along the coast at $21^{\circ} \mathrm{S}$ (Figure 13) was not part of a continuous undercurrent but of a southward meander visible in the horizontal geopotential fields. The $T-S$ diagrams corresponding to $21^{\circ} \mathrm{S}$ in May 1998 (Figure 9) continued to present surface STW, the SAW relative salinity minimum, and a weak ESSW signature, consistent with the absence of poleward flow.

[39] Thus, although the general return to climatological conditions is clear in May 1998, the offshore and northern part of the study region was dominated by a strong anticyclonic eddy. A larger-scale survey (not presented) revealed a tongue of surface STW extending southeast along the Peruvian coast [Blanco et al., 1999]. The eddy in the northern part of Figure 12 is part of a larger and stronger eddy centered to the north of the study region $\left(\sim 18^{\circ} \mathrm{S}\right.$, $72^{\circ} \mathrm{W}$ ) which appeared to be in the process of separating from the tip of that tongue.

[40] The IFOP survey in August 1998 found normal SSTs over most of the study area. Nearshore SSTs and salinities were low (by $1^{\circ}-2^{\circ} \mathrm{C}$ and $0.1-0.2 \mathrm{psu}$ ) owing to strong upwelling. Positive salinity anomalies in the northwest corner dropped to $\sim 0.1-0.2$ psu. $T-S$ curves from August 1998 along $21^{\circ} \mathrm{S}$ indicated no salinity values above 35.0, a large volume of SAW, and a weak presence of ESSW (Figure 9). Finally, a cruise in December 1998 found no sign of the warm, salty patch in the northwest.

\section{Discussion}

\subsection{Comparison to 1982-1983}

[41] Anomalies in sea level and SST (Figure 3) as well as of temperature with depth (Figure 2) in the 1997-1998 El Niño off northern Chile were similar in magnitude to those in the $1982-$ 1983 event. The El Niño of 1986-1987 was weaker, and that of 1991-1992 was shorter in duration. Both the 1982-1983 [Huyer et al., 1987; Fonseca, 1985] and 1997-1998 El Niño events consisted of two distinct sea level maxima (Figure 3), although the seasonal timing of the two pulses differed. If we consider the high sea levels and depressed isotherms during December-January in each event as representative of the classic El Niño timing, the 

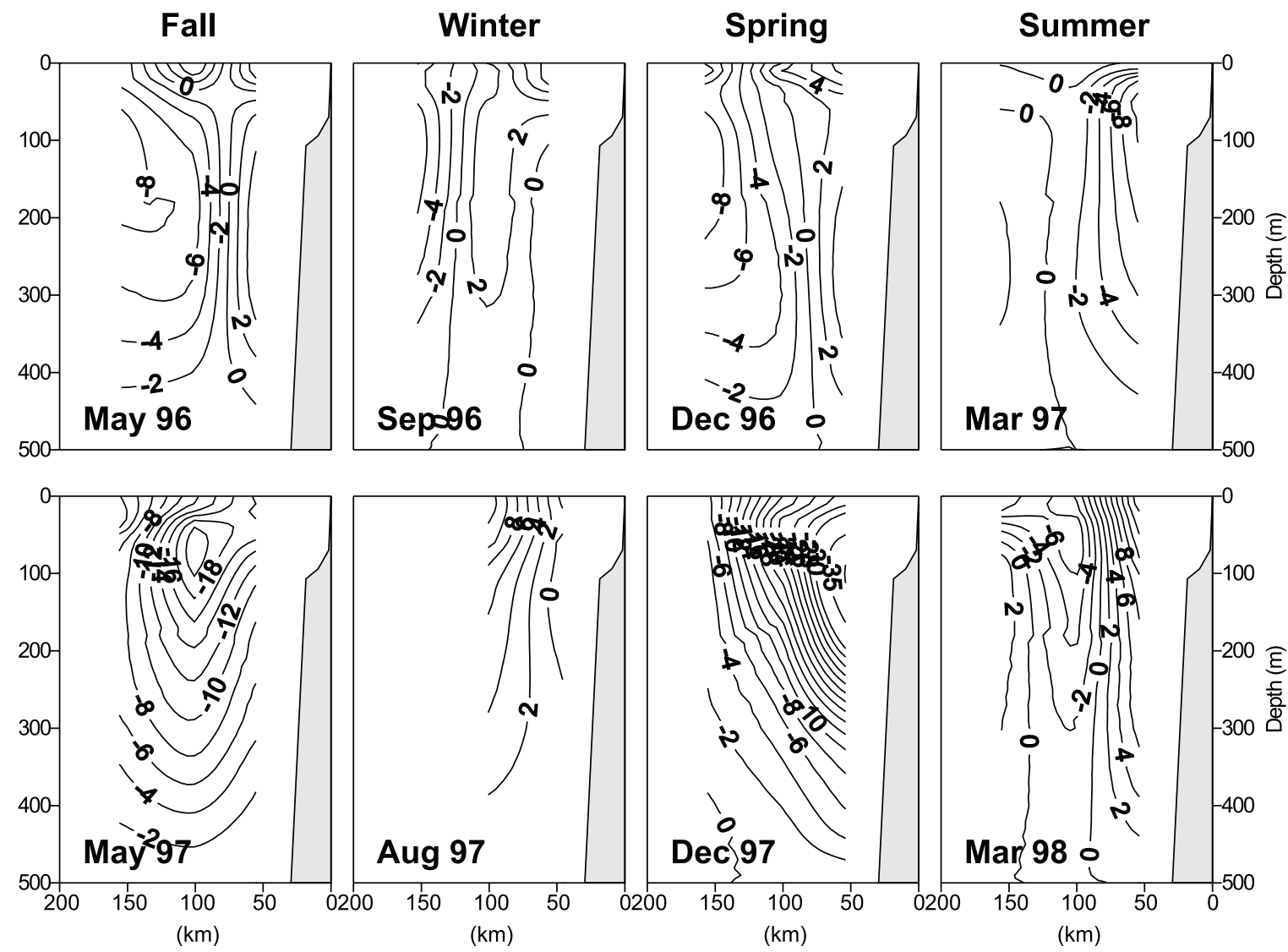

Figure 11. Alongshore geostrophic velocities relative to $500 \mathrm{dbar}$ along the section at $21^{\circ} \mathrm{S}$.

“other" pulse arrived afterward in 1982-1983, while in 1997 the other pulse arrived earlier.

[42] Sampling off Iquique during 1997-1998 (arrows in Figure 2) and the IFOP cruises covering $18^{\circ}-24^{\circ} \mathrm{S}$ captured both pulses and the relaxation periods. During 1982-1983 the sampling at Iquique was not frequent enough to separate the pulses. IFOP cruises were carried out in April and December 1982, March, May-June, August-September, October, and December 1983 [Blanco and Díaz, 1985; Kelly and Blanco, 1986]. Conditions in April 1982 were cool and fresh as observed in December 1996 and March 1997. East of $72^{\circ} \mathrm{W}$ the temperature anomalies were negative $\left(\sim 1^{\circ} \mathrm{C}\right)$, salinities were low $(<35)$, and surface geostrophic velocities were equatorward. The $15^{\circ} \mathrm{C}$ isotherm at $20.5^{\circ} \mathrm{S}$ was at $50 \mathrm{~m}$ offshore and shoaled toward the coast. In December 1982, during the first high sea level pulse, surface geostrophic velocities were strongly poleward from Arica to Antofagasta, and the $15^{\circ} \mathrm{C}$ isotherm was depressed to $100 \mathrm{~m}$ offshore and to $150 \mathrm{~m}$ at the coast. Temperature anomalies exceeded $3^{\circ} \mathrm{C}$ east of $73^{\circ} \mathrm{W}$ in the north and $72^{\circ} \mathrm{W}$ in the south. Salinity was $>35.3$ offshore north of Iquique, and values below 35.0 were only found south of Antofagasta. Conditions in December 1982 resembled those of May 1997, although they were more extreme in 1982. During the relaxation in March 1983 the $15^{\circ} \mathrm{C}$ isotherm off Iquique was between 50 and $100 \mathrm{~m}$, and shoaling toward the coast and surface geostrophic velocities were equatorward. SST anomalies of $4^{\circ} \mathrm{C}$ extended as far south as Antofagasta. Surface salinities were 35.6 offshore of Iquique and 35.3 at Antofagasta. March 1983 was comparable, with stronger anomalies, to August 1997. The second sea level maximum in May-June 1983 was accompanied by a deepening of the $15^{\circ} \mathrm{C}$ isotherm at Iquique to $100 \mathrm{~m}$. The survey revealed poleward surface geostrophic velocities, temperature anomalies exceeding $6^{\circ} \mathrm{C}$ north of $20^{\circ} \mathrm{S}$ and $4^{\circ} \mathrm{C}$ north of Antofagasta, and patchy salinities (35.3-35.6) north of Antofagasta. These conditions were comparable to those found in December 1997. IFOP surveys off northern Chile from August 1983 onward found generally equatorward surface geostrophic velocities and isotherms at normal depths. Positive anomalies in both surface temperature $\left(1-2^{\circ} \mathrm{C}\right)$ and salinity $(0.3 \mathrm{psu})$ persisted in the northwest corner of the study area until about June 1984. Thus the evolution of hydrographic conditions during the 1982-1983 El Niño was similar to that encountered in 1997-1998, i.e., two peaks in sea level accompanied by positive temperature and salinity anomalies and surface poleward flow.

[43] In the 1997-1998 El Niño, oxygen concentrations were above normal at the coast, as seen in the deeper than climatology $1 \mathrm{~mL} \mathrm{~L}^{-1}$ oxygen isopleth $(<100 \mathrm{~m})$ during the surveys in May and December 1997 and March 1998 (Figure 8). The depressed oxygen minimum can be explained by the increased volume of STW and the presence of SAW at middepth despite intensified poleward flow. Escribano [1998] observed increased oxygen concentrations concurrent with a sudden increase in temperature in the upper $80 \mathrm{~m}$ in May 1997 in a bay north of Antofagasta. By contrast, Fonseca [1985] reported anomalously low oxygen concentrations in December 1982, both at the surface (slight) and at $100 \mathrm{~m}$ (anomalies of $0.6-1.2 \mathrm{~mL} \mathrm{~L}^{-1}$ ); the largest anomalies occurred offshore and to the south. Fonseca [1985] inferred that the decreased oxygen concentrations were due to enhanced transport in the undercurrent, as the low oxygen requires a northern origin. This is consistent with the increased volume and shallower position of warmer ESSW water seen in the $T-S$ diagrams corresponding to December 1982 through December 1983 [Blanco and Díaz, 1985]. Likewise, the influence of SAW in 1982-1983 appeared to be less than climatology except toward the end of the event (September 1983 or later). Cruise data indicate that the near-shore oxygen minimum was deeper 

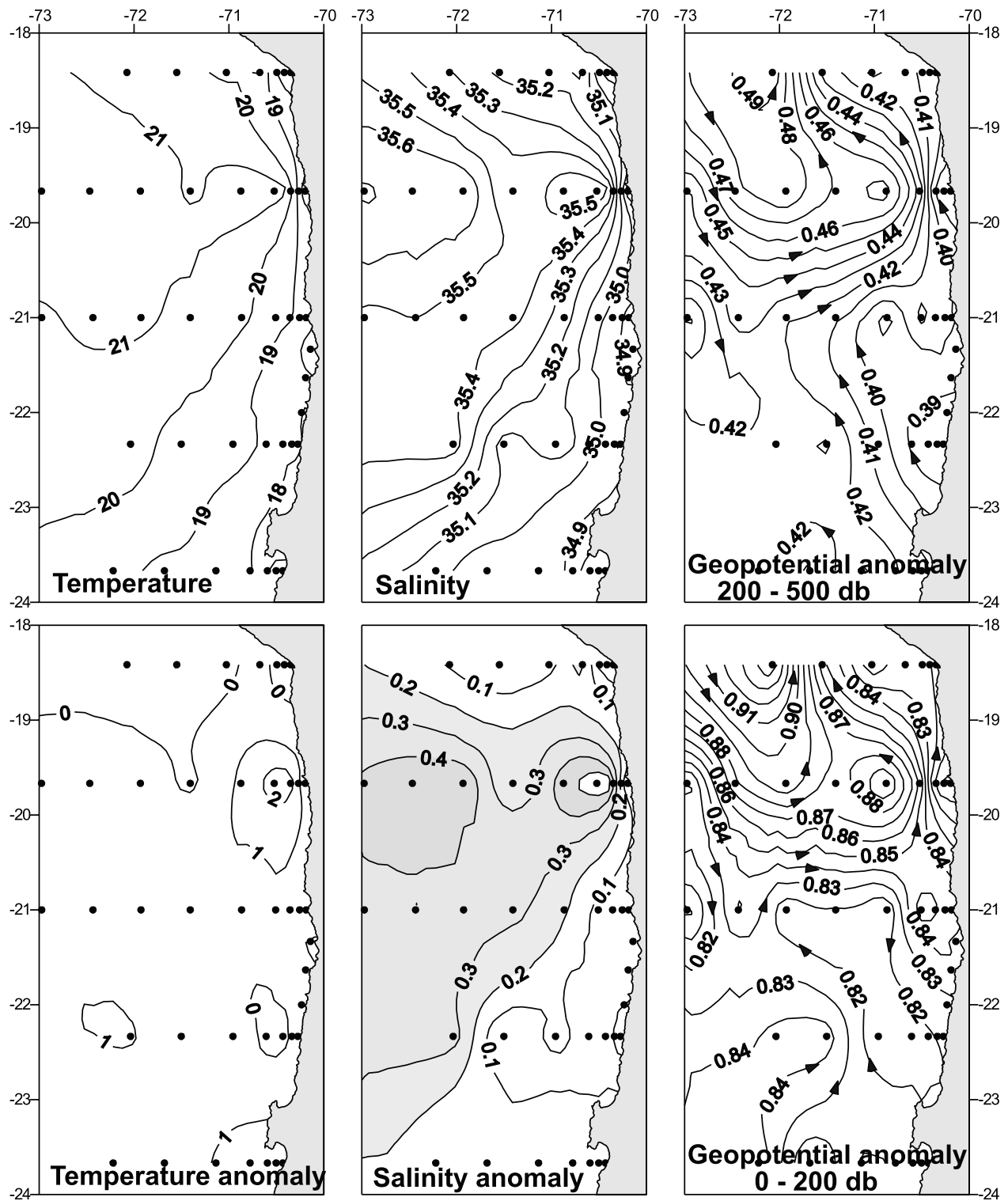

Figure 12. (top) SST, surface salinity, and geopotential anomaly (0/500 dbar) and (bottom) SST anomaly, surface salinity anomaly, and geopotential anomaly (200/500 dbar) for May 1998.

than usual in 1982 and 1983 [Kelly and Blanco, 1986]. Morales et al. [1996] reported that the layer of low dissolved oxygen $(<1$ $\mathrm{mL} \mathrm{L}^{-1}$ ) was shallower during cold or La Niña years, which is consistent with the observations from May 1996 to March 1997 (Figure 8).

\subsection{Role of CTWs in the Observed Hydrographic Changes}

[44] The initial rise in sea level during the 1997-1998 El Niño appears to have propagated poleward with the appropriate speed for a CTW at $\sim 250-300 \mathrm{~s} \mathrm{~km}^{-1} \mathrm{~d}^{-1}$ [e.g., Brink, 1982]. The same is true of other shorter period disturbances, including the more transient March sea level rise. However, conditions found during and following the pulses off northern Chile differed from the observations of Shaffer et al. [1997] in 1991-1992 in which the waves showed an approximate period of 50 days and a $50 \mathrm{~km}$ offshore decay scale for velocity. The poleward currents in May and December 1997 (Figures 10 and 11) extended much farther offshore than $50 \mathrm{~km}$, and the May velocity maximum was displaced from the coast, unlike the theoretical wave structure, which has maximum speeds at the coast decreasing rapidly offshore [Shaffer et al., 1997]. The evolution of the isotherm depth off $20.5^{\circ} \mathrm{S}$ included two periods of thermocline depression, each lasting 3-4 months, separated by $2-3$ months. This suggests a much longer period than 50 days, more like a semiannual period, although there may be 50 day signals that were not well sampled. From theory [Gill and Clarke, 1974], we expect the coastal ocean to adjust its circulation in response to changing forcing through the propagation of a series of CTWs of higher and higher modes. The arrival of the high sea level in May 1997 would be the first of these modes, beginning a process in which the regional circulation off northern Chile was modified for periods longer than those of the waves (the two sea level maxima and large-scale poleward flow). The severe displacement of the isotherms and isohalines within 50 $\mathrm{km}$ of the coast off Iquique in the December 1997 transects (Figures 6a and 7a) may include the signature of a passing lowfrequency CTW, associated with poleward flow and high sea levels. We propose that the major role of the CTWs is to trigger the two observed sea level maxima, depressing the thermocline and leading to maximum sea level and SST anomalies.

[45] During the periods of persistent poleward velocities, water with STW characteristics was advected southward and onshore, thus changing water properties off northern Chile over a period of 

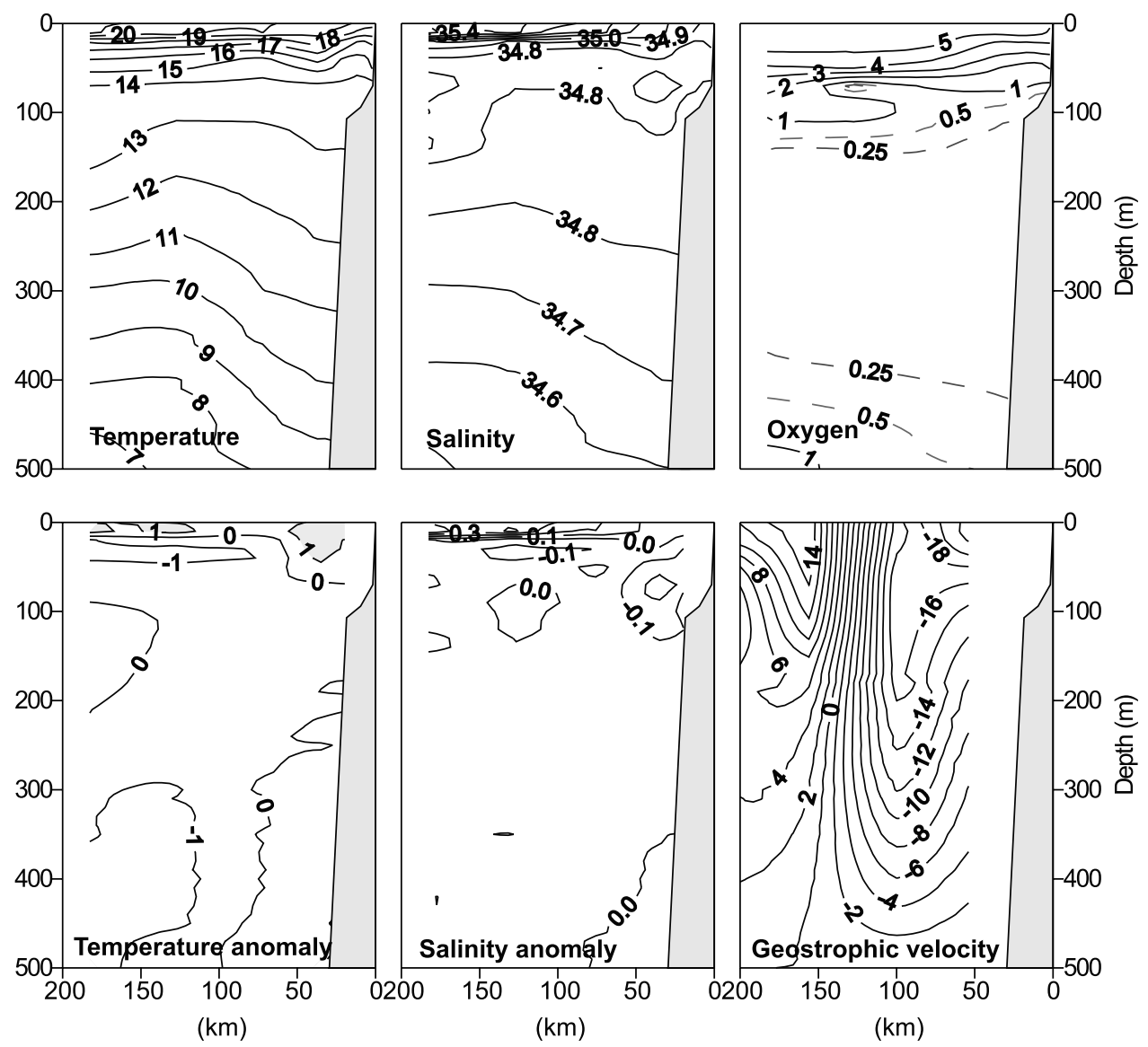

Figure 13. May 1998 sections at $21^{\circ} \mathrm{S}$ of temperature, salinity, geostrophic velocity relative to 500 dbar, salinity anomaly, temperature anomaly, and oxygen.

several months. The gradual shift in water mass properties, compared to the rapid increase in sea level and depression of isotherms, is seen in the increased anomalies of temperature and salinity between sea level maxima from May to December 1997. Velocities of $20-35 \mathrm{~cm} \mathrm{~s}^{-1}$ (Figure 11) over a month correspond to displacements of $500-900 \mathrm{~km}\left(5^{\circ}-9^{\circ}\right.$ of latitude). These velocities are comparable to those measured over periods of 2 months at the onset of the 1982-1983 El Niño off Peru [Smith, 1983]. The relaxation velocities (equatorward following the sea level maxima) are only one half to one third as large (Figure 11). Assuming the lower estimate of velocity and that the velocities lasted for 2 months, the water found off northern Chile at the end of the first pulse would have originated $1000 \mathrm{~km}$ to the north; it would have traveled half that distance north during the relaxation and then moved another $1000 \mathrm{~km}$ to the south during the second pulse. With a net displacement of $1500 \mathrm{~km}$ the water found off northern Chile in March 1998 would have a Peruvian source at $\sim 10^{\circ} \mathrm{S}$. An equatorward flow of $10 \mathrm{~cm} \mathrm{~s}^{-1}$ would require $\sim 6$ months to restore this water to its original position. This is consistent with observations in August 1998 that were close to climatology. We take this as the simplest explanation for the observed conditions off northern Chile in 1996-1998.

\section{Conclusions}

[46] 1. Cool, La Niña conditions prevailed in 1996: sea level anomalies were moderately negative off Peru and weakly negative off Chile. Surface temperatures and salinities in the region and to $100 \mathrm{~m}$ at $21^{\circ} \mathrm{S}$ were cool and fresh. The circulation was generally equatorward at the surface and weakly poleward at $200 \mathrm{~m}$.
Equatorward currents in the $100 \mathrm{~km}$ next to the coast are consistent with an increase in SAW and a decrease in STW.

[47] 2. In March 1997, May-July 1997, and October-February 1997-1998, pulses of high SST and sea level propagated from west to east along the equator [Chávez et al., 1998]. High monthly sea level anomalies along the South American coast extended to $37^{\circ} \mathrm{S}$ in May-July and October-February. The pulse of sea level in March 1997 was visible in the daily sea level records (not presented) though not in the monthly averages. Deeper isotherms and a $2^{\circ} \mathrm{C}$ temperature anomaly were observed in the upper $50 \mathrm{~m}$ at $20.5^{\circ} \mathrm{S}$

[48] 3. During the two sea level maxima the deepened isotherms led to positive temperature anomalies of $4^{\circ}-6^{\circ} \mathrm{C}$ to $50-150$ $\mathrm{m}$ depth and of $2^{\circ} \mathrm{C}$ down to $400 \mathrm{~m}$. The hydrographic surveys show strong $\left(20-35 \mathrm{~cm} \mathrm{~s}^{-1}\right)$ poleward flow extending through the water column beyond $400 \mathrm{~m}$. Both pulses were followed by weaker $\left(10 \mathrm{~cm} \mathrm{~s}^{-1}\right)$ equatorward flow.

[49] 4. The alongshore wind remained upwelling-favorable (equatorward) throughout the study period. Continued upwelling near shore is reflected in the water properties. In the north and center of the region, alongshore winds were weaker than usual (though still upwelling-favorable) during the first sea level maximum and may have contributed to that signal and the weaker relaxation.

[50] 5. The water mass properties during the sea level peaks correspond to unmodified STW near the surface and increased temperature in ESSW below $100 \mathrm{~m}$, consistent with the enhanced poleward flow. Increased onshore flow in the northern part of the region is reflected in a layer of SAW between 75 and $150 \mathrm{~m}$ that reaches the coast in March 1998. 
[51] 6. Although the timing of sea level maxima at the equator and along the South American coast is consistent with CTW propagation, the isotherm oscillations at Iquique suggest a period much longer than 50 days, and the offshore structure of the velocity did not conform to that of CTWs. We propose that the sudden sea level changes and strong poleward velocities reflect the propagation of a series of higher mode CTWs.

[52] 7. The water mass properties became progressively more modified after the initial pulse in May 1997. This was a consequence of the advection STW and ESSW into the region during the periods of persistent poleward flow and their removal by the weaker northward transport during the relaxation and recovery periods.

[53] 8. By May 1998, flow was again equatorward next to the coast, and SST had returned to the climatological mean over much of the region. Salinity remained anomalously high offshore and at $19.5^{\circ} \mathrm{S}$ at the coast, associated with an anticyclonic eddy. This eddy appeared to be a remnant of the thick layer of STW that moved southeast during the El Niño pulses.

[54] 9. Between August and December 1998, anomalous conditions disappeared. Thus warm El Niño conditions were observed off northern Chile for $\sim 1-1.5$ years.

[55] 10. Hydrographic conditions evolved during the 1982 1983 El Niño in a similar fashion to that in 1997-1998, although anomalies were larger in 1982-1983. April 1982 conditions (cool and fresh, surface equatorward flow) were comparable to December 1996 and March 1997. The first sea level maximum in December 1982 (with large positive anomalies in temperature and salinity and barotropic poleward flow) was similar to that in May 1997. The observed relaxation in March 1983 (reduced sea level, reduced temperature and salinity anomalies, and surface equatorward flow) corresponds to observations in August 1997. The second sea level peak in May-June 1983 was comparable to that observed in December 1997 (with large positive anomalies in temperature and salinity and barotropic poleward flow). In both events, positive surface anomalies were more persistent in the northwest of the study area where they remained until June 1984 (August 1998).

[56] Acknowledgments. Wind data were supplied by the Dirección Meteorológica de Chile, and temperature data at coastal tide gauges came from the Servicio Hidrográfico y Oceanográfico de la Armada de Chile. Monthly sea levels at the tide gauges were obtained from the University of Hawaii. Data collection and support for J.L.B. were provided by IFOP, with funding by the Fondo de Investigación Pesquera (projects FIP 95-05, 96-07, and 97-02). Funding for travel for all authors to collaborate in the analysis of these data came from an NSF supplement to grant OC-9711344 (part of the U.S. GLOBEC program). Additional funding for A.C.T. came from NASA grants NAG5-6558 and NAG5-6604 and NSF grant OCE-9711919 (part of the U.S. GLOBEC program). Additional funding for M.E.C. was provided by the NASA Ocean Biogeochemistry Program and by JPL grant 958128 (TOPEX) and NASA grants NAG5-4947 (EOS) and NAG5-6604 for P.T.S. The research described in this paper was carried out in part at the Jet Propulsion Laboratory, California Institute of Technology, and was sponsored by the National Science Foundation and the National Aeronautics and Space Administration.

\section{References}

Battisti, D. S., and E. S. Sarachik, Understanding and predicting ENSO, Rev. Geophys., 33, 1367-1376, 1995.

Bernal, P. A., F. L. Robles, and O. Rojas, Variabilidad física y biológica en la region meridional del sistema de corrientes Chile-Peru, Monogr. Biol. 2, 75-102, 1982.

Bilbao, P., Características fisícas del fenómeno de El Niño 1982-1983 en la costa de Chile, Oceaography thesis, Univ. Católica de Valparaíso, Valparaíso, Chile, 1992

Blanco, J. L., Variabilidad térmica y salina en la zona norte de Chile, IFOP data report, Inst. de Fomento Pesq., Valparaíso, Chile, 1996.
Blanco, J. L., and M. Díaz, Características oceanográficas y desarrollo de El Niño 1982-83 en la zona norte de Chile, Invest. Pesq. Chile, 32, 53-60, 1985.

Blanco, J. L., L. Pizarro, T. De la Cuadra, G. A. Camacho, R. Martinez y J. Quintana, Características meteorológicas y oceanográficas en el Pacífico Sudeste durante la declinación del evento El Niño $1997-$ 1998, Crucero Regional Conjunto, Mayo 1998, Special Publication, Comisión permanente del Pacífico Sur, Valparaiso, Chile, 1999.

Blanco, J. L., A. C. Thomas, M.-E. Carr, and P. T. Strub, Seasonal climatology of hydrographic conditions in the upwelling region off northern Chile, J. Geophys. Res., 106, 11,451-11,467, 2001.

Brink, K. H., A comparison of long coastal trapped wave theory with observations off Peru, J. Phys. Oceanogr., 12, 897-913, 1982.

Chávez, F. P., P. G. Strutton, and M. J. McPhaden, Biological-physical coupling in the central equatorial Pacific during the onset of the $1997-$ 1998 El Niño, Geophys. Res. Lett., 25, 3543-3546, 1998.

Comisión Permanente del Pacifico Sur, Informe final de la XIII Reunion del comité científico del programa ERFEN, Guayaquil, Novembre, 1998, Valparaíso, Chile1999.

Cornejo, M. P., and D. B. Enfield, Propagation and forcing of highfrequency sea level variability along the west coasst of South America, J. Geophys. Res., 92, 14,323-14,334, 1987.

Cucalon, E., Oceanographic variability off Ecuador associated with an El Niño event in 1982-1983, J. Geophys. Res., 92, 14,309-14,322, 1987.

Enfield, D. B., M. P. Cornejo-Rodriguez, R. L. Smith, and P. A. Newberger, The equatorial source of propagating variability along the Peru coast during the 1982-1983 El Niño, J. Geophys. Res., 92, 14,335-14,346, 1987.

Escribano, R., Population dynamics of Calanus chilensis in the Chilean Eastern Boundary Humboldt Current, Fish. Oceanogr., 7, 245-251, 1998.

Fonseca, T., Efectos físicos del fenómeno El Niño 1982-83 en la costa chilena, Invest. Pesq. Chile, 32, 61-68, 1985.

Gill, A. E., and A. J. Clarke, Wind-induced upwelling, coastal currents and sea level changes, Deep Sea Res., 21, 325-345, 1974.

Huyer, A., R. L. Smith, and T. Paluszkiewicz, Coastal upwelling off Peru during normal and El Niño times, 1981-1984, J. Geophys. Res, 92, $14,297-14,307,1987$

Kelly, R., and J. L. Blanco, Caracteristicas oceanograficas en el norte de Chile durante la declinacion de El Niño 1982-83, Invest. Pesq. Chile, 33, 77-90, 1986.

Morales, C. E., M. Braun, H. Reyes, J. L. Blanco, and A. G. Davies, Anchovy larval distribution in the coastal zone off northern Chile: The effect of low dissolved oxygen concentration and of a cold-warm sequence (1990-1995), Invest. Mar. Valparaíso Chile, 24, 77-96, 1996.

Neelin, J. D., and M. Latif, El Niño dynamics, Phys. Today, 51(12), 32-36, 1998 .

Neelin, J. D., M. Latif, and F.-F. Jin, Dynamics of coupled ocean-atmosphere models: The tropical problem, Annu. Rev. Fluid Mech., 26, 617-659, 1994.

Philander, S. G., El Niño, La Niña, and the Southern Oscillation, 289 pp., Academic, San Diego, Calif., 1990.

Shaffer, G., O. Pizarro, L. Djurfeldt, S. Salinas, and J. Rutllant, Circulation and low-frequency variability near the Chilean coast: Remotely forced fluctuations during the 1991-92 El Niño, J. Phys. Oceanogr., 27, $217-$ 235, 1997

Smith, R. L., Poleward propagating perturbations in currents and sea level along the Peru coast, J. Geophys. Res., 83, 6083-6092, 1978.

Smith, R. L., Peru coastal currents during El Niño: 1976 and 1982, Science, 221, 1397-1399, 1983.

Strub, P. T., J. M. Mesias, V. Montecino, J. Rutllant, and S. Salinas, Coastal ocean circulation off western South America, in The Sea, vol. 11, edited by A. R. Robinson and K. H. Brink, pp. 273-313, John Wiley, New York, 1998.

J. L. Blanco, Center for Coastal Physical Oceanography, Old Dominion University, Norfolk, VA 23508, USA.

M.-E. Carr, Jet Propulsion Laboratory, MS 300-323, California Institute of Technology, 4800 Oak Grove Drive, Pasadena, CA 91009, USA. (mec@pacific.jpl.nasa.gov)

P. T. Strub, College of Oceanic and Atmospheric Sciences, Oregon State University, Corvallis, OR 97331, USA.

A. C. Thomas, School of Marine Sciences, University of Maine, Orono, ME 04473, USA. 

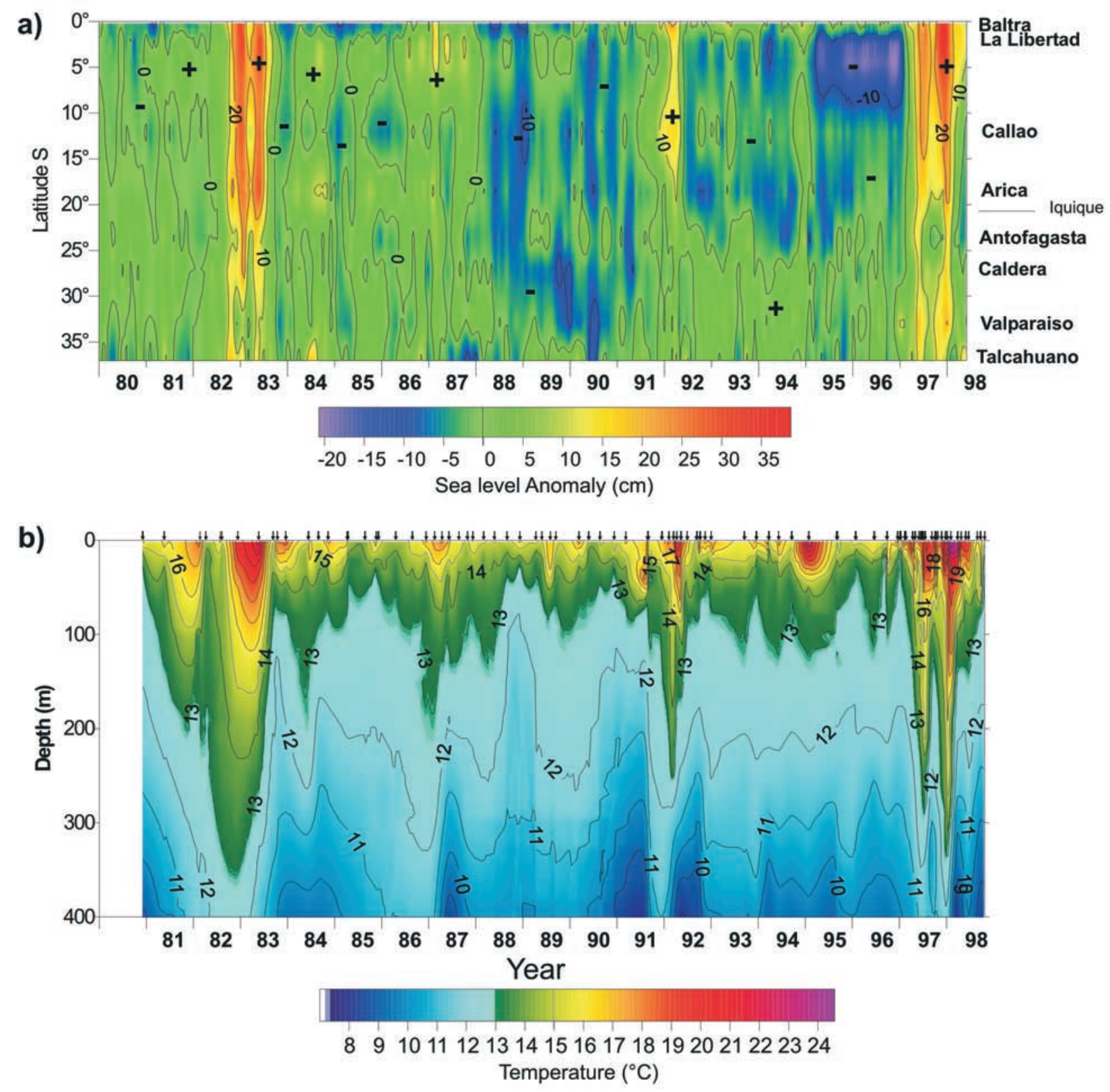

Figure 2. (a) Time-latitude plot of monthly sea surface height anomalies from coastal tide gauges along the west coast of South American (locations at the right) from 1980 to 1996. Plus and minus indicate the sign of the anomaly; (b) time-depth plot of temperatures $10 \mathrm{~km}$ offshore of Iquique. Sampling is indicated by arrows. 